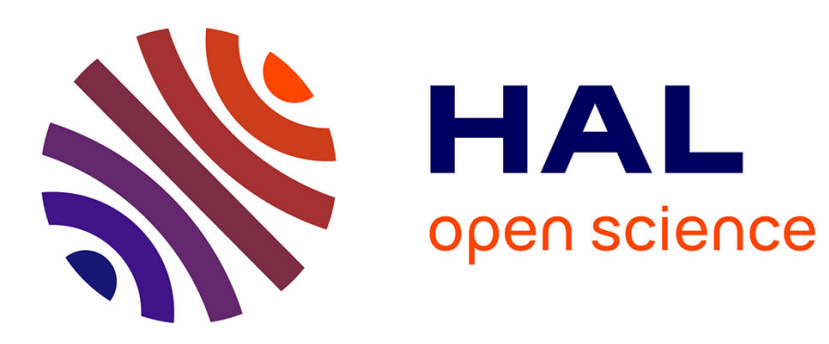

\title{
First 40Ar/39Ar dating of intense Late Palaeogene lateritic weathering in Peninsular India
}

Nicolas J. Bonnet, Anicet Beauvais, Nicolas Arnaud, Dominique Chardon, Mudlappa Jayananda

\section{- To cite this version:}

Nicolas J. Bonnet, Anicet Beauvais, Nicolas Arnaud, Dominique Chardon, Mudlappa Jayananda. First 40Ar/39Ar dating of intense Late Palaeogene lateritic weathering in Peninsular India. Earth and Planetary Science Letters, 2014, 386, pp.126-137. 10.1016/j.epsl.2013.11.002 . hal-01097320

\section{HAL Id: hal-01097320 \\ https://hal.science/hal-01097320}

Submitted on 2 Jan 2017

HAL is a multi-disciplinary open access archive for the deposit and dissemination of scientific research documents, whether they are published or not. The documents may come from teaching and research institutions in France or abroad, or from public or private research centers.
L'archive ouverte pluridisciplinaire HAL, est destinée au dépôt et à la diffusion de documents scientifiques de niveau recherche, publiés ou non, émanant des établissements d'enseignement et de recherche français ou étrangers, des laboratoires publics ou privés. 
$1 \quad$ First ${ }^{40} \mathrm{Ar} /{ }^{39} \mathrm{Ar}$ dating of intense Late Palaeogene lateritic weathering

\section{in Peninsular India}

3

4 Nicolas Bonnet $^{1^{*}}$, Anicet Beauvais ${ }^{1}$, Nicolas Arnaud ${ }^{2}$, Dominique Chardon ${ }^{3,4,5}$,

Mudlappa Jayananda ${ }^{6}$

6

7 ' ${ }^{1}$ Aix-Marseille Université (AMU), IRD, CNRS, CEREGE UM34, BP 80, 13545 Aix-en-

8 Provence, Cedex 4, France

$9 \quad{ }^{2}$ Université de Montpellier 2, Géosciences Montpellier, UMR CNRS 5243, 34095 Montpellier, 10

${ }^{6}$ Department of Geology, Centre of Advanced Studies, University of Delhi, Delhi 110007, India 16 


\section{Abstract}

Lateritic surface processes have shaped large platform and cratons of the tropical belt. Constraining the timing of such processes is crucial to decipher their role in cratonic morphogenesis and their response to long-term climatic change and lithospheric deformation. Weathering histories have been documented for South America, Africa and Australia, but precise time constraints of the lateritic weathering processes in South India are still lacking. We present ${ }^{40} \mathrm{Ar} /{ }^{39} \mathrm{Ar}$ ages of supergene cryptomelane (K-Mn oxide) formed in the Sandur Mn ore deposits exposed on the highest lateritic paleolandsurface that once covered the Mysore plateau and the adjacent Deccan Traps. Significant ${ }^{40} \mathrm{Ar} /{ }^{39} \mathrm{Ar}$ ages are estimated between $\sim 36$ and $\sim 26 \mathrm{Ma}$ from well-defined plateaus in step heating ${ }^{39} \mathrm{Ar}$ release spectra and from best-fitted inverse isochrones. These ages constitute firm time constraints that document intense late Eocene-Oligocene lateritic weathering over Peninsular India under the influence of warm and wet climate comparable to that prevailing in tropical humid forests. These results imply that Southern India was weathered between $~ 36$ and 26 Ma and may have been dissected mostly in the Neogene.

Keywords: ${ }^{40} \mathrm{Ar} /{ }^{39} \mathrm{Ar}$ radiometric dating; Cryptomelane; Supergene Mn-ore deposits; Lateritic paleolandsurface; Sandur Greenstone Belt; South India 


\section{Introduction}

52

Exposed laterites and lateritic duricrusts on relics of paleolandsurfaces in cratonic domains result from successive long-duration chemical weathering and erosion processes, and as such represent morphoclimatic fingerprints of tropical regions (Ollier, 1988; Bárdossy and Aleva, 1990; Thomas, 1994; Tardy and Roquin, 1998; Beauvais and Chardon, 2013). Since the first definition and description of laterites in South India (Buchanan, 1807), many studies were conducted on Indian lateritic formations (Subramanian and Mani, 1978; Babu, 1981; Sahasrabudhe and Deshmukh, 1981; Krishna Rao et al., 1989b; Widdowson and Cox, 1996; Widdowson and Gunnell, 1999), including manganiferous supergene ore deposits (Sawkar, 1981; Krishna Rao et al., 1982, 1989a; Dessai, 1985; Roy, 1992; Mohapatra et al., 1996; Sethumadhav et al., 2010). Except few geological stratigraphic constraints, radiometric dating of surface processes involved in the formation and evolution of Indian lateritic paleolandsurfaces are still lacking. Laterites are interlayered with marine sequences of late Eocene and early Miocene age (McGowran et al., 1977; Prasad, 1983). Lateritisation processes have also been indirectly dated with Neogene palynofossils found in colluvial/alluvial sediments overlying in-situ formed Mn ore deposits $~ 100 \mathrm{~km}$ south of Belgaum (Fig. 1). These fossils constrain intense weathering that led to Mn ore concentration to be Neogene at the latest (Krishna Rao et al., 1989a). The age of lateritic weathering has also been roughly estimated on the basis of the paleomagnetic properties of iron oxides formed in laterites around $16^{\circ} \mathrm{N}$ (Schmidt et al., 1983), i.e., "Early Tertiary" (Paleogene?) for the high-level Belgaum laterites and "Late Tertiary" (Neogene?) for the low-level laterites found west of the Western Ghats escarpment (Fig.1). 

elements (Al, Fe, Mn) in residual laterites and depletion of more soluble elements $(\mathrm{Na}$, $\mathrm{K}, \mathrm{Si}, \mathrm{Ca}$ ). Potassium, $\mathrm{Na}$ and/or Ba may, however, be retained by supergene $\mathrm{Mn}$ oxides in large crystallographic lacuna existing between the $\mathrm{MnO}_{6}$ octahedra chains that define the typical tunnel-structure of the hollandite manganese oxide group. Cryptomelane belongs to this group with the general stoichiometric formulae $\mathrm{K}_{\mathrm{x}} \mathrm{Mn}^{\mathrm{IV}}{ }_{8-\mathrm{x}} \mathrm{Mn}^{\mathrm{III}}{ }_{\mathrm{x}} \mathrm{O}_{16}, \mathrm{x}$ ranging from 0.2 to 1 and $\mathrm{K}_{\mathrm{x}}$ counterbalancing $\mathrm{Mn}^{\mathrm{III}}$ substitution for $\mathrm{Mn}^{\mathrm{IV}}$ (Burns and Burns, 1979; Turner and Buseck, 1979; Post and Burnham, 1986; Pasero, 2005).

Cryptomelane is a major Mn oxide of many lateritic Mn-ore deposits in South India (Sivaprakash and Phil, 1980; Krishna Rao et al., 1982; Mohapatra et al., 1996; Sethumadhav et al., 2010). This mineral hosts radioactive ${ }^{40} \mathrm{~K}$ atoms, which can decay into ${ }^{40} \mathrm{Ar}$. The high radiogenic ${ }^{40} \mathrm{Ar}$ retentive power of cryptomelane makes this mineral a suitable chronometer for ${ }^{40} \mathrm{Ar} /{ }^{39} \mathrm{Ar}$ step heating dating of weathering processes in lateritic soils including duricrusts and manganiferous ore deposits (Vasconcelos et al., 1992; Vasconcelos et al., 1994a; Ruffet et al., 1996; Vasconcelos, 1999). This study quantifies the radiometric ages of lateritic weathering processes that have affected the rocks of the Dharwar craton on the Mysore Plateau by ${ }^{40} \mathrm{Ar} /{ }^{39} \mathrm{Ar}$ dating of cryptomelane from supergene Mn-ore deposits. We focus on the Fe-Mn sedimentary formations belonging to the Sandur Greenstone Belt (SGB) (Figs. 1 and 2a), which hosts the biggest Indian manganese reserve (Kameshwar et al., 2000). Our

94 results provide tangible time constraints (Late Eocene - Oligocene) on the paleoweathering processes and morphoclimatic evolution of the potentially oldest lateritic paleolandsurface preserved on the Mysore plateau and Traps in southern India. 


\section{Geological and geomorphological setting}

\subsection{Sandur Greenstone Belt geology}

The SGB is a synform-shape greenstone belt that consists of mafic/ultramafic volcanics and sediments (Fig. 2a) having undergone low-grade regional metamorphism during latest Archean orogeny that shaped the Dharwar craton (Roy and Biswas, 1979; Mukhopadhyay and Matin, 1993; Chadwick et al., 1996; Chardon et al., 2008). The sedimentary sequences contain elements of metavolcanic rock, which are relatively rich in $\mathrm{Ni}, \mathrm{Cr}, \mathrm{Co}$ and $\mathrm{Sc}$. The upper part of the greenstone stratigraphic pile includes platform-like sediments bearing stromatolites, $\mathrm{Mn}$ formations and carbonaceous $\mathrm{Mn}$ phyllites (Fig. 2a).

In the eastern part of the belt, the upper part of the sequence includes banded iron formations (BIF), felsic volcanics and terrigenous sediments (Fig. 2a). SHRIMP U$\mathrm{Pb}$ dating of zircon in two interlayered felsic volcanics indicate ages ranging from 2651 \pm 18 Ma to $2659 \pm 40$ (Nutman et al., 1996). The BIF and Fe-Mn formations are related to marine transgression and regression cycles, respectively (Roy, 2006). These cycles implied alternating chemical and clastic sedimentation, which is also evidenced by specific iron formation facies and argillites within the BIF (Manikyamba et al., 1993). The lower part of the sequence is confined to the Deogiri region and is essentially composed of manganiferous stromatolitic limestones, dolomites and argillites (Fig. 2a) while the upper part is richer in Fe (Roy, 2000). Iron and Mn fractionation was controlled during eustatic sea-level variations by differentiated redox conditions of two stratified water masses on the shallow and deep shelf (Roy, 1992; Manikyamba and Naqvi, 1997). The Fe-Mn sediments have later been affected by low-grade metamorphism by $2475 \pm 65 \mathrm{Ma}$ (whole rock $\mathrm{Pb} / \mathrm{Pb}$ isochron dating), which is the 
maximal recrystallisation age of the limestones (Russell et al., 1996; Chadwick et al., 2000). Such a metamorphism led to Mn enrichment of the sediments (Roy, 2000), which are composed of Mn-carbonates, argillites, arenites and phyllites (Fig. 2a), and are the main protores of the SGB Mn-ore deposits. These deposits grade upward into supergene weathering materials (Roy, 2006).

\subsection{Geomorphology of southern India and Sandur Greenstone Belt}

The geomorphology of southern India consists of high-elevation surfaces occurring as relics of a differentiated landscape developed on the Dharwar craton and Deccan traps (Fig. 1), and low-elevation surfaces along the western coast (Radhakrishna, 1993), both being overlain by laterites (Widdowson and Cox, 1996; Widdowson, 1997). The regional eastern dip of the high-elevation surfaces is interpreted to result from eastward tilting of Peninsular India due to the Seychelles rifting and Deccan Traps events ( 65-63 Ma) (Radhakrishna, 1993). On the Deccan Traps, bauxitic lateritic weathering of the highest preserved landsurface must be younger than $62.3 \pm 0.6 \mathrm{Ma}$, which is the age of the youngest basalts (Courtillot et al., 1986; Pande, 2002). On the Traps and the Mysore Plateau, relics of two younger surfaces step below the plateau remnants of the high bauxitic surface (900-1000 m). The three erosion surfaces remain as sparse geomorphic relics at the scale of the Mysore plateau, and have been numbered $\mathrm{S} 2, \mathrm{~S} 3$ and $\mathrm{S} 3{ }_{\mathrm{d}}$, the latter being a denudation degradation landform of S3 (Gunnell, 1998). Spatially reduced relics of the highest massifs also overhang the Mysore plateau (Fig. 1).

Landsurfaces $\mathrm{S} 2, \mathrm{~S} 3$ and $\mathrm{S} 3_{\mathrm{d}}$ are also identified on the SGB relief (Figs. 2b-c). The S2 surface levels the summits of the belt over an altitude range of 900 to $1100 \mathrm{~m}$ 
and exposes deep in situ formed weathering mantles capped by Fe-Mn and $\mathrm{Mn}$

147 duricrusts at altitudes of $\sim 1000-1016 \mathrm{~m}$. Our study is mainly focused on the Mn ore

148 open-pit mines carved in this surface (Figs. 2b-c). Relicts of paleo-land surface S3

149 extends below S2 over an altitude range of 750 to $850 \mathrm{~m}$ (Fig. 2c), and are covered by

150 in-situ formed lateritic weathering profiles capped by iron duricrust instead of Mn ore

151 concentrations. Relicts of land surface $S 3_{d}$ occur as benches below the $\mathrm{S} 3$ surface over

152 an altitude range of 700-750 m above the modern river network (Figs. 2c). The $S 3_{d}$

153 surface is covered by reworked erosional materials including ferricrete and bedrock

154 clasts originated from S3 lateritic profiles, sharing most characteristics with West

155 African glacis/pediments (Beauvais and Chardon, 2013), but this surface is not affected

156 by a late ferruginous or manganiferous lateritic duricrusting.

157

158 3. Material and methods

159 3.1. Ore bodies description and sampling

160 We have sampled across the main Mn ore bodies of the SGB deposits, which

161 formed within weathered meta-sedimentary phyllites at different depths below the top

162 of landsurface S2 at 1012-1015 m altitudes (Fig. 3). Description of samples precisely

163 located on open-pit mine benches allowed the establishment of log sections (Fig. 3b and

164 3d). In Kappataswamy pit (N 1459’59” E 76³2’42”, Fig. 3a), the first ore body was

165 sampled between 856 and 893 m of elevation along the E-W log section 1 on the

166 western benches of the pit, and the second one between 904 to $935 \mathrm{~m}$ along the N-S log

167 section 2 on the eastern benches (Fig. 3b). The third ore body is located in Channanghi

168 KMK-E pit (N 1459'50'’ E 76³4'37', Fig. 3c) at an elevation range of 926 to $994 \mathrm{~m}$

169 (log section 3, Figure 3d). The Mn-ore bodies are composed of different petrographic 
facies. The float and platty Mn-ores constitute the stratiform ore type, which is

171

172

173

174

175

176

177

178

179

180

181

182

183

184

185

186

187

188

189

190

191

192

193

conformably bedded within weathered mangan-phyllites preserving this metasedimentary protore structure (Mishra, 1978). The massive Mn ore is found between $850 \mathrm{~m}$ and $892 \mathrm{~m}$ elevation in the first section, between $904 \mathrm{~m}$ and $912 \mathrm{~m}$ elevation in the second ore body of the Kappataswamy pit (Fig. 3b), and between 926 and $982 \mathrm{~m}$ elevation in Channanghi KMK-E pit (Fig. 3d). The massive ore is a podiform type with cavity fillings (geodes) and botryoidal structures, which formed by secondary Mn supergene enrichments (Mishra, 1978). Iron-Mn duricrust of $\sim 10 \mathrm{~m}$ thickness caps the two Mn-ore deposits immediately above a segregated/tabular ore body (Figs. 3b-d).

The samples collected in the Mn-ore deposits (Fig. 3b-d) were cut with a circular saw to get the best angle for mineralogical observations on metallographic quality polished thin sections (200-300 $\mu$ m-thick) made from the sawed fragments (Fig. 4a). Symmetrically to the thin sections, $500 \mu \mathrm{m}$-thick slabs are prepared for sub-sampling of the target cryptomelane grains suitable for ${ }^{40} \mathrm{Ar} /{ }^{39} \mathrm{Ar}$ dating (Hénocque et al., 1998).

3.2. Analytical techniques and cryptomelane characterisation Reflected light microscopy and X-ray micro fluorescence ( $\mu$-XRF) analyses allow precise characterisation of K-enriched Mn-oxide (cryptomelane) on the polished thin sections (Fig. 4b-c). Microscopic observations of thin sections were accomplished using a Leica DM-RXP microscope. The $\mu$-XRF measurements were completed on slabs using a X-ray microscope (XGT7000, Horiba Jobin Yvon) equipped with a X-ray guide tube producing a finely focused and high-intensity beam with a $100 \mu \mathrm{m}$ spot size, $\mathrm{Rh} \mathrm{X}$-ray tube, accelerating voltage of $30 \mathrm{kV}$ and current of $1 \mathrm{~mA}$. X-ray emission from the irradiated sample was detected via an energy dispersive X-ray (EDX) spectrometer 
equipped with a liquid-nitrogen-cooled high purity Si detector. Micro mapping of the coupled Mn-K occurrences on slabs contributes to precise identification of cryptomelane, while Fe maps document the occurrence of Fe oxihydroxides (Fig. 4c). A Scanning electron microscope (SEM) has been also used for fine-scale observations of the cryptomelane crystals (Fig. 4d). Electron probe micro chemical analysis (EPMA) of minerals on polished thin sections was completed using a CAMECA SX-100 electron microprobe equipped with five wavelength-dispersive X-ray spectrometers (WDS). Cryptomelane grains were separated from the slabs by hand picking.

202 Cryptomelane separates were crushed to produce powders $(<64 \mu \mathrm{m})$, which were 203 analyzed by XRD using a Panalytical X'Pert Pro MPD with a Co K $\alpha$ X-ray source $(\lambda=$ 204 $1.79 \AA$ ) operating at $40 \mathrm{kV}$ and $40 \mathrm{~mA}$. The system is equipped with a linear $\mathrm{X}^{\prime}$ Celerator detector and a flat monochromator. The analysis range was $10-85^{\circ} 2 \theta$ with a step size of $0.033^{\circ}$ and a counting time of $10 \mathrm{~s}$ per step.

After ultrasonically cleaning in absolute ethanol and conditioning in aluminium foil packets, other separated grains were irradiated for 50 hours in the TRIGA Mark-II reactor of Pavia University (Italia). The standard Taylor Creek Rhyolite sanidine 2 (TCRs-2) monitor, with an age of 28.05 Ma \pm 0.08 (Baksi et al., 1996), was analysed

211 after every ten unknown samples to allow determination of the factor J. After a two-

212 month "cooling" period, the irradiated cryptomelane grains were loaded in a double 213 vacuum Staudacher-type furnace for step heating Ar isotopes measurements. The 214 furnace temperature was calibrated by means of a classical thermocouple, and the gas 215 purification was accomplished using a cold trap with liquid air and Al-Zr AP10 getters 216 (one hot, one cold) for 8 minutes before the introduction into the VG3600 mass 217 spectrometer. One minute was allowed for equilibration before analysis. ${ }^{40} \mathrm{Ar}$ and ${ }^{39} \mathrm{Ar}$ 
218 were measured on a Faraday cup with a resistor of $10^{11} \mathrm{ohm}$, while ${ }^{39} \mathrm{Ar},{ }^{38} \mathrm{Ar},{ }^{37} \mathrm{Ar}$, 219 and ${ }^{36} \mathrm{Ar}$ were analysed using a scintillator and photomultiplier after interaction on a Daly plate. The analytical data are reported in data repositories (Tables DR1 and DR2),

221

222

223

224

225

226

227

228

229

230

231

232

233

234

235

236

237

238

239

240

241 and the errors are quoted at the $1 \sigma$ level. Ages were analysed in two ways: plateaus and inverse isochrones. Plateaus ages were calculated from at least three consecutive steps comprising up to $50 \%$ of total ${ }^{39} \mathrm{Ar}_{\mathrm{K}}$ released and overlapping at the $2 \sigma$ confidence level (Fleck et al., 1977; Maluski, 1985). Alternatively, plateau ages encompassing two steps releasing 30-40\% ${ }^{39} \mathrm{Ar}$ were also defined as "plateau-like" or "pseudo-plateau” (e.g., Feng and Vasconcelos, 2007; Vasconcelos et al., 2013). Ages derived from best-fit inverse isochrones in ${ }^{36} \mathrm{Ar} /{ }^{40} \mathrm{Ar}$ vs. ${ }^{39} \mathrm{Ar} /{ }^{40} \mathrm{Ar}$ correlation diagrams (Roddick et al., 1980) were accepted when mean square weighted deviation (MSWD) was less than 2.5 and the ${ }^{40} \mathrm{Ar} /{ }^{36} \mathrm{Ar}$ intercept within $2 \sigma$ from the $\left({ }^{40} \mathrm{Ar} /{ }^{36} \mathrm{Ar}\right.$ ) atm value of $298.56 \pm 0.31$ (Lee et al., 2006; Renne et al., 2009), since supergene cryptomelane crystallised at shallow depth, and thus incorporated excess argon, if any, in the atmospheric ratio. Age spectra also show the variations of ${ }^{40} \mathrm{Ar} *$ and $\mathrm{K} / \mathrm{Ca}$ (derived from ${ }^{39} \mathrm{Ar} /{ }^{37} \mathrm{Ar}$ ) to track the compositional effects on age.

\section{Results and Discussion}

Six samples (KPA-2.1, KPA-2.5, KPA-9, KPA-10, KPA-12a and KPA-12b) from the Kappataswamy pit (Fig. 3b) and one (KMK-3) from the Channanghi KMK-E pit (Fig. 3d) were analysed and dated. KPA-9 and KPA-12 show the platy preserved meta-sedimentary structure with Mn pods, while KPA-2, KPA-10 and KMK-3 are rather massive with cavity crystallisations (geode) and/or botryoidal pod concretions. 
244 SEM imaging (Fig. 4), and characterized by microchemical (EPMA) and XRD analyses

245 of separated grains (Figs. 5 and 6, Table 1). Samples KPA-9, KPA-12a and KPA-12b

246 are the richest in cryptomelane, which occurs as cryptocrystalline plasmic domains

247 formed within preserved inherited protore microstructures (Figs. 5a-c). Appropriately,

248 sample KPA-9 exhibits a relict of Si-Mn sedimentary protore with residual smoothed

249 small size quartz grains preserved in acicular cryptocrystalline cryptomelane (Fig. 4d).

250 The two different generations of cryptomelane (Fig. 5a) have the same stoichiometric

251 composition (Table 1). Separated grain of KPA-9 mainly contains cryptomelane, but

252 also pyrolusite $\left(\beta \mathrm{MnO}_{2}\right)$ and quartz (Fig. 6). Sample KPA-12a is composed of two

253 cryptomelane generations, the latest one filling the micro porosity developed across the

254 earliest generation and/or the other mineral components such as pyrolusite and $\mathrm{Fe}$

255 oxihydroxides (Fig. 5b). The stoichiometric composition is very close to that of KPA-9

256 (Table. 1). Sample KPA-12b is very rich in cryptomelane (Fig. 5c) with higher K

257 content than KPA-12a (Table. 1). The two separated grains are dominantly composed of

258 cryptomelane but pyrolusite and goethite $(\gamma \mathrm{FeOOH})$ are also present (Fig. 6).

259 Samples KPA-2, KPA-10 and KMK-3 are composed of successive cryptomelane

260 crystallisations organized in banded overgrowth microstructures associated with other

261 Mn oxides (Figs. 5d-f and 6). In the sample KPA-2, the first three bands are pure

262 cryptomelane, the fourth is a cryptocrystalline mixture of nsutite and cryptomelane, and

263 the fifth is dominantly cryptomelane, while pyrolusite crystallized in a cavity (Fig. 5).

264 The cryptomelane crystals analysed in the different bands have different stoichiometric

265 compositions with $\mathrm{K}$ varying from 0.45 to 0.57 atoms (Table 1). Sample KPA-10 
consists of a $\sim 5 \mathrm{~mm}$ size cryptomelane concretion with a transition zone of less than 1 mm separating it from pyrolusite (Fig. 5e). Separated grain of KPA-10 is mainly composed of cryptomelane with $0.5 \mathrm{~K}$ atoms (Table 1 ). Small quantities of pyrolusite, goethite and hematite $\left(\mathrm{Fe}_{2} \mathrm{O}_{3}\right)$ are also present (Fig. 6). Sample KMK-3 (Fig. 5f) is a concretion of cryptomelane with less than $1.5 \mathrm{wt} . \% \mathrm{~K}$ (Table 1$)$. The outer rims are composed of lithiophorite (Al,Li) $\mathrm{MnO}_{2}(\mathrm{OH})_{2}$ and nsutite $\left(\gamma \mathrm{MnO}_{2}\right)($ Fig. 5f), which also occur as minor fractions in the XRD analysis of the separated grain (Fig. 6).

273

4.2. ${ }^{40} \mathrm{Ar} /{ }^{39} \mathrm{Ar}$ ages of cryptomelane

Two kinds of ${ }^{40} \mathrm{Ar} /{ }^{39} \mathrm{Ar}$ age spectra are distinguished from the step heating 276 degassing depending on their shape and interpretation. The first group displays regular

${ }^{39} \mathrm{Ar}$ release spectra allowing calculation of plateau ages (Fig. 7a-e), which are commonly defined at the $2 \sigma$ error and accounting at least for $40 \%$ of the total ${ }^{39} \mathrm{Ar}$ released from the sample (Vasconcelos and Conroy, 2003; Feng and Vasconcelos, 2007;

280 Beauvais et al., 2008). The second group corresponds to disturbed ${ }^{39}$ Ar release spectra (Fig. 8), which are more problematic to interpret. The analytical data are provided in the data repository tables DR1 and DR2.

\subsubsection{Regular ${ }^{40} \mathrm{Ar}{ }^{\beta^{9}}$ Ar age spectra} The ${ }^{40} \mathrm{Ar} /{ }^{39} \mathrm{Ar}$ age spectra from the first group have been obtained from the first generation of cryptomelane crystallized in the meta-sedimentary protore (Figs. 5a and $5 \mathrm{c}, 7 \mathrm{a}$ and $7 \mathrm{c}$ ), and for cryptomelane crystallisations in banded overgrowth microstructures of botryoids (Figs. 5f and 7d) or geodes (Figs. 5d-e, 7b and 7e). In each 
case the calculated plateau and pseudo-plateau ages agree with statistically meaningful inverse isochron ages estimated in the correlation diagrams (Fig. 7).

However, these spectra present some anomalies at low and high temperatures steps. The age spectrum of KPA-9 (Fig. 7a) shows younger individual ages (steps 10 to 13), which may reflect the degassing of a late cryptomelane crystallisation (Figs. $4 \mathrm{~b}$ and 5a). The sample KPA-10 displays an age spectrum with a clear ascending "stair case" pattern at low temperature (steps 1 to 7 ) with young ages affected by quite a large standard deviation (Fig. 7b). The isochron suggests a moderate excess of ${ }^{40} \mathrm{Ar}$, which was interpreted as the result of primary mineral weathering (McDougall and Harrison, 1988; Vasconcelos et al., 1994a), which is unlikely in this sample (Figs. 5e and 7b, Table 1). The higher amounts of released ${ }^{40} \mathrm{Ar} *$ and ${ }^{39} \mathrm{Ar}$ in intermediate temperatures (step 8 to 11), however, allow the best estimation of the cryptomelane crystallisation age (Vasconcelos, 1999; Hautmann and Lippolt, 2000; Li and Vasconcelos, 2002; Vasconcelos and Conroy, 2003; Feng and Vasconcelos, 2007). Sample KPA-12b is characterised by well-constrained plateau and isochron ages (Fig.7c).

The age spectrum of KMK-3 exhibits an ascending "stair case" pattern at high temperature (steps 8, 9, 10, 13 and 14) with older ages than the plateau age (Fig. 7d). In such a case, it is usually admitted that radiogenic argon is released by two cryptomelane phases, the older one retaining radiogenic ${ }^{40} \mathrm{Ar}$ better than the younger one (Feng and Vasconcelos, 2007) resulting in a maximum plateau age estimate and an older integrated age (Li and Vasconcelos, 2002). The plateau age of KMK-3 has also quite a large error due to relatively low K content (Table 1 and Fig. 7d), and higher atmospheric correction, the isochron being less sensible and thus more precise. 

calculation of a standard plateau age (Fleck et al., 1977). Pseudo-plateaus ages have

314 been, however, previously estimated from similar spectra by considering only two 315 concordant steps including $\sim 40 \%$ of ${ }^{39}$ Ar released (e.g., Feng and Vasconcelos, 2007;

316 Vasconcelos et al., 2013). Two pseudo-plateaus occur in intermediate temperature steps $3174-5$ and 7-8, allowing for a concordant age estimate of $35.86 \pm 1.10$ Ma by combining 318 the four steps at the $2 \sigma$ level (Fig. 7e). We note that the best-fitted isochron supports a 319 similar age (Fig. 7e). The high temperature steps 13 to 16 suggest a hypogene 320 contaminant (Vasconcelos et al., 1994a; Ruffet et al., 1996; Li and Vasconcelos, 2002), which could have aged the intermediate steps (e.g., the step 6). The low K content extraction in high temperature steps could have also suffered from imprecise blank corrections. Therefore, similarly to the sample KMK-3 (Fig. 7d), the best-fitted isochron might reasonably provide a more precise age (Fig. 7e).

\subsubsection{Disturbed ${ }^{40} \mathrm{Ar}{ }^{39}$ Ar age spectra} The ${ }^{39} \mathrm{Ar}$ release spectra from the second group are characterized by an upward convex shape (Fig. 8) suggestive of a mixing of two or more supergene cryptomelane phases (Vasconcelos et al., 1995; Ruffet et al., 1996; Hautmann and Lippolt, 2000), 330 which may result from the handpicking of single grains. Phase mixing is obvious in sample KPA-12a showing late cryptomelane crystallisation precipitated into the porosity $(\leq 500 \mu \mathrm{m})$ generated by the dissolution of a first plasmic cryptomelane generation (Fig. 5b). Such a process may result in remobilization of low energy sites

334 (Colin et al., 2005; Beauvais et al., 2008). Phase mixing often occurs during separation 335 of grains from multiple overgrowth bands (Vasconcelos and Conroy, 2003). The grain 
of KPA-2.5 was tentatively separated from a thin band $(\sim 500 \mu \mathrm{m})$ between a late pyrolusite crystallisation in a geodic void and a band composed of a mixing of cryptomelane and nsutite (Fig. 5d). The growth rate of cryptomelane crystals in banded overgrowth structures (botryoids or geodes) is generally very low (Vasconcelos et al., 1992; Dammer et al., 1996; Hénocque et al., 1998) and may result in vey small size ( $\leq 1$ $\mu \mathrm{m})$ intimately intergrown cryptomelane phases in a same grain (Vaconcelos et al., 1994b; Vasconcelos, 1999).

The pronounced upward convex shape of ${ }^{39} \mathrm{Ar}$ release spectra precludes plateau age calculation, while correlation diagrams only allow estimation of minimum and maximum ages of the oldest and youngest mixing phases, respectively (Fig. 8a-b). Each step of the ${ }^{39}$ Ar release spectra yields a mixing age of the intergrown cryptomelane generations (Vasconcelos, 1999; Vasconcelos and Conroy, 2003; Feng and Vasconcelos, 2007), implying that the ages in low and high temperature steps are overestimates of the youngest phase, while the ages in intermediate temperature steps are underestimates of the oldest phase (see also Ruffet et al., 1996; Beauvais et al., 2008). This interpretation is mainly based on previous experiments (Vasconcelos et al, 1995), which showed a maximal degassing of ${ }^{40} \mathrm{Ar} *$ and ${ }^{39} \mathrm{Ar}$ between $700^{\circ} \mathrm{C}$ and $900^{\circ} \mathrm{C}$ with a peak at $800^{\circ} \mathrm{C}$. In such a range of temperatures, the two isotopic components are release from the mineral structures (Vasconcelos et al., 1994b). Therefore, only maximum and minimum ages might be estimated from upward convex spectra in the temperature range specific of supergene cryptomelane degassing (Fig. 8). For KPA-2.5 (Fig. 8a), a minimum age of $\sim 46 \mathrm{Ma}$ (step 7) and a maximum age of $\sim 30 \mathrm{Ma}$ (step 10) could be at best estimated for the crystallisation of the earliest and latest cryptomelane phases, respectively. For KPA-12a the maximum and minimum ages of $\sim 29$ Ma (step 
10) and $~ 34 \mathrm{Ma}$ (step 8) are estimated for the youngest and oldest phases, respectively, in agreement with the estimated isochron age limits, although the MSWD value of the second isochron is quite large (Fig. 8b).

363

\subsubsection{Cryptomelane ${ }^{40} \mathrm{Ar} \mathrm{P}^{39}$ Ar ages summary}

Despite mineral phase mixing of some samples, five significant plateau and isochron ages are estimated between $\sim 26$ and $36 \mathrm{Ma}$. The older ages $(\sim 33.5$ and 36 Ma) are obtained either for the first cryptomelane generation in samples showing the preserved meta-sedimentary protore structure (Figs. 5a-c, 7a-c) or the first crystallisation band of an overgrowth geodic microstructure (Fig. 5d and 7e). The younger ages ( 26-28 Ma) characterize the late cryptomelane crystallisations of banded overgrowth microstructures (Figs. 5e-f, $7 \mathrm{~b}$ and $7 \mathrm{~d}$ ). The ages of the different mixing phases of KPA-2.5 and KPA-12a cannot be precisely determined. However, the two cryptomelane phase of KPA-12a (Fig. 5b) may have crystallised between $\sim 29$ Ma and $34 \mathrm{Ma}$ (Fig. 8c) that bracket the age of KPA-12b (Fig. 7c) sampled on the same open mine bench. The maximum age ( $30 \mathrm{Ma})$ estimated for the youngest cryptomelane of KPA-2.5 is quite realistic compared to the older cryptomelane grain (KPA-2.1) separated from the same sample (Fig. 5d and 7e). Despite their limited number, our results usefully document Late Paleogene weathering history of southern India.

4.3. Potential implications for lateritic weathering and morphogenesis in southern India The formation of cryptomelane in Mn-ore deposits is enhanced on landsurfaces covered by a humid tropical forest reflecting warm and/or at least wet climatic conditions (Vasconcelos et al., 1994a), like those prevailing for bauxite genesis in 
tropical cratonic regions (Bárdossy and Aleva, 1990). Such hydroclimatic conditions are required for complete weathering of K-phyllosilicates into kaolinite with release of $\mathrm{K}^{+}$ in $\mathrm{Mn}^{2+}$-rich acidic solutions $(\mathrm{pH} \sim 4.5-5)$ that may ultimately lead to cryptomelane crystallisation under appropriate redox conditions (Parc et al., 1989). Therefore, massive formation of cryptomelane in Mn ore deposits and/or lateritic weathering profiles is a good indicator of humid/warm paleoclimatic conditions (Vasconcelos et al., 1994a; Vasconcelos and Conroy, 2003; Beauvais et al., 2008). Under such climatic conditions, wide areas were colonised by humid tropical forests over most of peninsular India (Kent and Muttoni, 2008; Chatterjee et al., 2013) enhancing the pervasive development of lateritic weathering profiles with differential sequestration of $\mathrm{Al}, \mathrm{Fe}$ and $\mathrm{Mn}$. On the basis of global paleoclimatic reconstructions (e.g., Parrish et al., 1982), Bárdossy and Aleva (1990) argued for intermittent Cenozoic bauxitic weathering in South India. Such a bauxitic weathering intermittency was not observed in West Africa, where bauxites preserved in current landscapes have been dated from Late Palaeocene to Eocene at the latest (Prasad, 1983; Colin et al., 2005; Beauvais et al., 2008; Beauvais and Chardon, 2013). Nevertheless, two stages of lateritic weathering processes have been described in the bauxitic deposits of the Boknur-Navge plateau near Belgaum (Krishna Rao et al., 1989b) (Fig. 1). The first bauxitic stage characterizes the syngenetic lateritic weathering of the Deccan basalts under the action of slightly acidic meteoric waters, whereas the second stage is a late weathering epigenetic process of the early bauxite, under the effect of highly acidic meteoric Si-rich waters (Krishna Rao et al., 1989b). The Boknur-Navge bauxitic plateau is also a remnant of paleolandsurface S2 correlated to the S2 remnant of the SGB (Gunnell, 1998). Syngenetic bauxitic weathering on paleolandsurface S2 was likely active in the "Early Tertiary" (Paleogene 
?) as suggested by paleomagnetic investigations on Fe-oxihydroxides in bauxites and laterites of the nearby Belgaum area (Schmidt et al., 1983; Kumar, 1986). Although no

410 precise ${ }^{40} \mathrm{Ar}^{39}{ }^{39} \mathrm{Ar}$ age correlative of syngenetic bauxitic weathering of the Traps basalts

411 was obtained in this study, lateritic weathering up to $~ 46$ Ma may not be precluded

412 (Fig. 8a). Epigenetic lateritic weathering of paleolandsurface S2 (Krishna Rao et al., 413 1989b) could however be recorded by our ${ }^{40} \mathrm{Ar} /{ }^{39} \mathrm{Ar}$ ages set.

414 The obtained ages $(\sim 26, \sim 28, \sim 33.5$ and $\sim 36 \mathrm{Ma})$ attest for intense Late Eocene 415 to Mid-Oligocene lateritic weathering(s) of the highest paleolandsurface (S2) preserved 416 as sparse relics on both the Mysore plateau and the Deccan Traps. These results suggest 417 that the high-elevation landsurface of Peninsular India evolved under a wet and warm 418 climate over a protracted period in the Late Paleogene, essentially during the Oligocene. 419 Repeated lateritic weathering between 26 and 36 Ma apparently correlates with low 420 clastic sediment fluxes and dominant carbonate sedimentation on the Arabian sea margin (Campanile et al., 2008) but the links between inland weathering, erosion and 422 offshore sedimentation are poorly understood. Our ${ }^{40} \mathrm{Ar} /{ }^{39} \mathrm{Ar}$ results might also suggest 423 that the dissection and rejuvenation of the high-elevation lateritic surface of Peninsular India took place in the Neogene as classically inferred (Radhakrishna, 1993). However, the relative contributions of lithospheric deformation and climate change to geomorphic rejuvenation of Peninsular India in the Neogene remain to be investigated.

\section{Conclusion}

We provide time constraints on lateritic weathering having affected Southern India by using ${ }^{40} \mathrm{Ar} /{ }^{39} \mathrm{Ar}$ radiometric dating of supergene cryptomelane in Mn ore deposits underlying a relict paleolandsurface (S2) that once covered the Mysore plateau 


\section{2}

and Deccan Traps. Well-constrained plateau ages and best-fitted inverse isochrons allow defining ${ }^{40} \mathrm{Ar} /{ }^{39} \mathrm{Ar}$ ages at $~ 26, \sim 28, \sim 33.5$ and $\sim 36 \mathrm{Ma}$. These results document intense lateritic weathering in Southern India during the latest Eocene and the Oligocene under the effect of warm and wet climate similar to that prevailing in humid forest tropical environments. More specifically, the highest regional lateritic paleolandsurface (S2) of Peninsular India underwent chemical weathering at least between $\sim 36$ and $\sim 26$ Ma and was possibly dissected and rejuvenated afterwards, which suggests that most of the current relief of South Indian high-elevation terrains was acquired in the Neogene.

\section{Acknowledgements}

We are thankful to the PhD school (ED251, AMU, OSU Pytheas), which allocated to NB a grant from the French Ministry of Research and Superior Education. We also thank IRD and INSU for financial supports (AB). Bujkesh was our guide during a three weeks field trip. S.R. Sridhar, M.P. Deshpande and K. Raman are gratefully thanked to having allowed us the sampling of the Deogiri Mn ore deposits. Thanks to the assistance of Prakash Babu in the mining open pits. C. Demeurie (Thin section Lab) made the polished thin sections. This work also benefited of technical helps from D. Borschneck (XRD and $\mu$ XRF), Y. Galy (SEM), J-P. Ambrosi (chemical supplies), D. Merlet (EPMA), P. Münch and F. Lecoeur (Argon radiochronology). Jason Price and an anonymous reviewer are also thanked for useful remarks and suggestions. 


\section{References}

457 Babu, P.V.L.P., 1981. Laterite as an unconformity plane in the evolution of the South

458

459

460

461

462

463

464

465

466

467

468

469

470

471

472

473

474

475

476

477

478

479 Indian peninsula - a synthesis, International Seminar on Lateritisation Processes (Trivandrum, India 11-14 December, 1979). Balkema, A. A., Rotterdam, pp. 302307.

Baksi, A.K., Archibald, D.A., Farrar, E., 1996. Intercalibration of ${ }^{40} \mathrm{Ar}^{39} \mathrm{Ar}$ dating standards. Chem. Geol. 129, 307-324. doi: 10.1016/0009-2541(95)00154-9

Bárdossy, G., Aleva, G.J.J., 1990. Lateritic bauxites. Elsevier, Amsterdam, The Netherlands.

Beauvais, A., Chardon, D., 2013. Modes, tempo, and spatial variability of Cenozoic cratonic denudation: The West African example. Geochemis. Geophys. Geosyst. 14, 1590-1608. doi: 10-1002/ggge.20093

Beauvais, A., Ruffet, G., Hénocque, O., Colin, F., 2008. Chemical and physical erosion rhythms of the West African Cenozoic morphogenesis: $\mathrm{The}^{39} \mathrm{Ar}-{ }^{40} \mathrm{Ar}$ dating of supergene K-Mn oxides. J. Geophys. Res. - Earth Surf. 113, F04007. doi: 10.1029/2008jf000996

Buchanan, F., 1807. A journey through the countries of Mysore, Canara and Malabar. Asian Educational Services, New-Delhi, India.

Burns, R.G., Burns, V.M., 1979. Manganese oxides, Marine Minerals. Mineral. Soc. Am., 1-46.

Campanile, D.J., Nambiar, C.G., Bishop, P., Widdowson, M., Brownn, R., 2008. Sedimentation record in the Konkan Kerala Basin: implications for the evolution of theWestern Ghats and the Western Indian passive margin. Basin Res. 20, 3-22. doi: 10.1111/j.1365-2117.2007.00341.x 
Chadwick, B., Vasudev, V., Ahmed, N., 1996. The Sandur schist belt and its adjacent plutonic rocks implications for Late Archaean crustal evolution in Karnataka. J. Geol. Soc. India 47, 635-639.

Chadwick, B., Vasudev, V.N., Hegde, G.V., 2000. The Dharwar craton, southern India, interpreted as the result of Late Archaean oblique convergence. Precamb. Res. 99, 91-111. 487

Chardon, D., Jayananda, M., Chetty, T.R., Peucat, J.-J., 2008. Precambrian continental strain and shear zone patterns: South Indian case. J. Geophys. Res. 113, B08402. doi: 10.1029/2007JB005299

Chatterjee, S., Goswami, A., Scotese, C.R., 2013. The longest voyage: Tectonic, magmatic, and paleoclimatic evolution of the Indian plate during its northward flight from Gondwana to Asia. Gondwana Res. 23, 238-267. doi:

492 10.1016/j.gr.2012.07.001

493

Colin, F., Beauvais, A., Ruffet, G., Hénocque, O., 2005. First ${ }^{40} \mathrm{Ar} /{ }^{39} \mathrm{Ar}$ geochronology of lateritic manganiferous pisolites: Implications for the Palaeogene history of a West African landscape. Earth Planet. Sci. Lett. 238, 172-188. doi:

Courtillot, V., Besse, J., Vandamme, D., Montigny, R., Jaeger, J.-J., Cappetta, H., 1986. Deccan flood basalts at the Cretaceous/Tertiary boundary? Earth Planet. Sci. Lett. 80, 361-374.

501

Dammer, D., Chivas, A., McDougall, I., 1996. Isotopic dating of supergene manganese 502 oxides from the Groote Eylandt deposit, Northern territory, Australia. Econ. geol. 91, 386-401. 
503

504

505

506

507

508

509

510

511

512

513

514

515

516

517

518

519

520

521

522

523

524

525

526

Dessai, A., 1985. An appraisal of the manganese ore deposits of Goa, India. Proceedings of the Indian National Science Academy, Part A. Physical sciences $51,1021-1032$.

Feng, Y.X., Vasconcelos, P.M., 2007. Chronology of Pleistocene weathering processes, southeast Queensland, Australia. Earth Planet. Sci. Lett. 263, 275-287. doi:10.1016/j.eps1.2007.08.036

Fleck, R.J., Sutter, J.F., Elliot, D.H., 1977. Interpretation of discordant ${ }^{40} \mathrm{Ar} /{ }^{39} \mathrm{Ar}$ agespectra of mesozoic tholeiites from antarctica. Geochim. Cosmochim. Acta 41, $15-32$.

Gunnell, Y., 1998. The interaction between geological structure and global tectonics in multistoreyed landscape development: a denudation chronology of the South Indian shield. Basin Res. 10, 281-310.

Hautmann, S., Lippolt, H.J., 2000. ${ }^{40} \mathrm{Ar} /{ }^{39} \mathrm{Ar}$ dating of central European K-Mn oxides a chronological framework of supergene alteration processes during the Neogene. Chem. Geol. 170(1-4), 37-80.

Hénocque, O., Ruffet, G., Colin, F., Féraud, G., 1998. ${ }^{40} \mathrm{Ar} /{ }^{39} \mathrm{Ar}$ dating of West African lateritic cryptomelanes. Geochim. Cosmochim. Acta 62, 2739-2756.

Kameshwar, D.R., Thambi, P.I., Srinivasamurthy, V., Sheriff, M.A.N.A., Shanmugam, P., Chayapathi, N., Panduranga, R., Jagannathachar, L.G., Naik, R.H., Vidyadharan, K.T., 2000. Final report on Sandur manganese exploration, Bellary district, Karnataka. Unpub. Prog. Rep. Geol. Surv. Ind. For the FS 54, 411-414.

Kent, D.V., Muttoni, G., 2008. Equatorial convergence of India and early Cenozoic climate trends. Proc. Nat. Acad. Sci. 105, 16065-16070. doi: 10.1073/pnas.0805382105 
527

528

529

530

531

532

533

534

535

536

537

538

539

540

541

542

543

544

545

546

547

548

Krishna Rao, B., Muzamil Ahmed, M., Janardhana, M.R., 1989a. Age of manganiferous laterite of Uttara Kanada district, Karnataka. J. Geol. Soc. India 34, 413-420.

Krishna Rao, B., Satish, P.N., Sethumadhav, M.S., 1989b. Syngenetic and Epigenetic features and genesis of the beauxite-bearing laterite of Boknur-Navge, Belgaum district, Karnataka. J. Geol. Soc. India 34, 46-60.

Krishna Rao, B., Srinivasan, R., Ramachandra, B.L., Sreenivas, B.L., 1982. Mode of occurrence and origin of manganese ores of Shimoga district, Karnataka. J. Geol. Soc. India 23, 226-235.

Kumar, A., 1986. Palaeolatitudes and the age of Indian laterites. Palaeogeogr. Palaeoclim. Palaeoecol. 53, 231-237.

Lee J-Y, Marti, K., Severinghaus, J.P., Kawamura, K., Yoo, H-S., Lee, J.B., Kim, J.S., 2006. A redetermination of the isotopic abundances of atmospheric Ar. Geochim. Cosmochim. Acta 70, 4507-4512. doi:10.1016/j.gca.2006.06.1563

Li, J.W., Vasconcelos, P.M., 2002. Cenozoic continental weathering and its implications for the palaeoclimate: evidence from ${ }^{40} \mathrm{Ar} /{ }^{39} \mathrm{Ar}$ geochronology of supergene K-Mn oxides in Mt Tabor, central Queensland, Australia. Earth Planet. Sci. Lett. 200, 223-239. doi:10.1016/j.eps1.2007.01.021

Maluski, H., 1985. Méthode Argon 39 - Argon 40 : Principe et applications aux minéraux des roches terrestres. Masson, Paris, France.

Manikyamba, C., Balaram, V., Naqvi, S.M., 1993. Geochemical signatures of polygenetic origin of a banded iron formation (BIF) of the Archean Sandur greenstone belt (schist belt) Karnataka nucleus, India. Precamb. Res. 61, 137-164. 
549 Manikyamba, C., Naqvi, S.M., 1997. Mineralogy and geochemistry of Archaean

550

551

552

553

554

555

556

557

558

559

560

561

562

563

564

565

566

567

568

569

570

571

572 greenstone belt-hosted Mn formations and deposits of the Dharwar Craton: Redox potential of proto-oceans. Geol. Soci., London, Spec. Publi. 119, 91-103.

McDougall, I., Harrison, T.M., 1988. Geochronology and thermochronology by the ${ }^{40} \mathrm{Ar} /{ }^{39} \mathrm{Ar}$ method. Oxford Univ. Press., New York.

McGowran, B., Rutland, R.W.R., Twidale, C.R., 1977. Discussion: Age and origin of laterite and silcrete duricrusts and their relationship to episodic tectonism in the mid-north of South Australia. J. Geol. Soc. Australia 24, 421-422.

Mishra, R.N., 1978. Exploration planing for Sandur manganese ores. J. Geol. Soc. India $19,446-453$.

Mohapatra, B.K., Rao, D.S., Nayak, B.D., Sahoo, R.K., 1996. Mineralogical and chemical characteristics of ferromanganese ores from Sandur, Karnataka, India. J. Miner. Petrol. Econ. Geol. 91, 46 - 61.

Mukhopadhyay, D., Matin, A., 1993. The structural anatomy of the Sandur schist belta greenstone belt in the Dharwar craton of South India. J. Struc. Geol. 15, 309322.

Nutman, A.P., Chadwick, B., Krishna Rao, B., Vasudev, V.N., 1996. SHRIMP U/Pb zircon ages of acid volcanic rocks in the Chitradurga and Sandur Groups and granites adjacent to the Sandur Schist Belt, Karnataka. J. Geol. Soc. India 47, 153164.

Ollier, C.D., 1988. Deep Weathering, Groundwater and Climate. Geog. Annal. Series A, Physic. Geog. 70, 285-290.

Pande, K., 2002. Age and duration of the Deccan Traps, India: A review of radiometric and paleomagnetic constraints. J. Earth Syst. Sci. 111, 115-123. 
573 Parc, S., Nahon, D., Tardy, Y., Vieillard, P., 1989. Estimated solubility products and

574

575

576

577

578

579

580

581

582

583

584

585

586

587

588

589

590

591

592

593

594

595 field of stability for cryptomelane, nsutite, birnessite and lithiophorite based on natural lateritic weathering sequences. Am. Mineral. 74, 466-475.

Parrish, J.T., Ziegler, A., Scotese, C.R., 1982. Rainfall patterns and the distribution of coals and evaporites in the Mesozoic and Cenozoic. Palaeogeogr. Palaeoclim. Palaeoecol. 40, 67-101.

Pasero, M., 2005. A short outline of the tunnel oxides. Rev. Miner. Geochem. 57, 291305. doi:10.2138/rmg.2005.57.9

Post, J.E., Burnham, C.W., 1986. Modeling tunnel-cation displacements in hollandites using structure-energy calculations. Am. Mineral. 71, 1178-1185.

Prasad, G., 1983. A review of the early Tertiary bauxite event in South America, Africa and India. J. Afric. Earth Sci. (1983) 1, 305-313.

Radhakrishna, B.P., 1993. Neogene uplift and geomorphic rejuvenation of the Indian Peninsula. Current Science 64(11/12), 787-793.

Renne, P.R., Cassata, W.S., Morgan, L.E., 2009. The isotopic composition of atmospheric argon and 40Ar/39Ar geochronology: time for a change. Quat. Geochron. 4, 288-298.

Roddick, J.C., Cliff, R.A., Rex, D.C., 1980. The evolution of excess argon in alpine biotites $\mathrm{A}^{40}-\mathrm{Ar}^{39} \mathrm{Ar}$ analysis. Earth Planet. Sci. Lett. 48, 185-208.

Roy, S., 1992. Environments and processes of Manganese Deposition. Econ. Geol. 87, $1218-1236$.

Roy, S., 2000. Late Archean initiation of manganese metallogenesis: its significance and environmental controls. Ore Geol. Rev. 17, 179-198. 
596

597

598

599

600

601

602

603

604

605

606

607

608

609

610

611

612

613

614 Schmidt, P.W., Prasad, V., Ramam, P.K., 1983. Magnetic ages of some Indian laterites.

615

616

617

618

Roy, S., 2006. Sedimentary manganese metallogenesis in response to the evolution of the Earth system. Earth-Sci. Rev. 77, 273-305. doi: 10.1016/j.earscirev.2006.03.004

Roy, S., Biswas, S.K., 1979. Metamorphic history of the Sandur schist belt, Karnataka. J. Geol. Soc. India 20, 179-187.

Ruffet G., Innocent, C., Michard, A., Féraud, G., Beauvais, A., Nahon, D., Hamelin, B., 1996. A geochronological ${ }^{40} \mathrm{Ar} /{ }^{39} \mathrm{Ar}$ and ${ }^{87} \mathrm{Rb} /{ }^{87} \mathrm{Sr}$ study of K-Mn oxides from the weathering sequence of Azul (Brazil). Geochim. Cosmochim. Acta 60, 22192232.

Russell, J., Chadwick, B., Rao, B.K., Vasudev, V.N., 1996. Whole-rock Pb/Pb isotopic ages of Late Archaean limestones, Karnataka, India. Precamb. Res. 78, 261-272.

Sahasrabudhe, Y.S., Deshmukh, S.S., 1981. The laterites of the Maharashtra State. Lateritisation processes, International Seminar on Lateritisation Processes (Trivandrum, India 11-14 December, 1979). Balkema, A. A., Rotterdam, pp. 209220.

Sawkar, R.H., 1981. Geology of the manganese ore deposits of North Kanara district, Karnataka state, India, in: Varentsov, I.M. (Ed.), Manganese Deposits on Continents, 2 ed. Grassely, London, pp. 279-295. Palaeogeogr. Palaeoclim. Palaeoecol. 44, 185-202.

Sethumadhav, M.S., Gunnell, Y., Ahmed, M.M., Chinnaiah, 2010. Late Archean manganese mineralization and younger supergene manganese ores in the AnmodBisgod region, Western Dharwar Craton, southern India: Geological 
619

620

621

622

623

624

625

626

627

628

629

630

631

632

633

634

635

636

637

638

639

640

641

642

characterisation, palaeoenvironmental history, and geomorphological setting. Ore Geol. Rev. 38, 70-89. doi: 10.1016/j.oregeorev.2010.06.001

Sivaprakash, C.B., Phil, D., 1980. Mineralogy and geochemistry of some manganeseiron deposits, Karnataka, India. Trans. Inst. Min. Metal., Section B-applied Earth Science 90, 174-182.

Subramanian, K.S., Mani, G., 1978. Geomorphic significance of bauxite below MioPliocene sediments in the West Coast. Symp. Morph. Evol. Landforms, Dec. 1978, New Delhi, 83-87.

Tardy , Y., Roquin, C., 1998. Dérive des continents paleoclimats et altérations tropicales. BRGM, Orléans, France.

Thomas, M.F., 1994. Geomorphology in the tropics. A study of weathering and denudation in low latitudes. John Wiley \& Sons Ltd, Chichester, England.

Turner, S., Buseck, P.R., 1979. Manganese Oxide Tunnel Structures and Their Intergrowths. Science 203, 456-458.

Vasconcelos, P., 1999. K-Ar and ${ }^{40} \mathrm{Ar} /{ }^{39} \mathrm{Ar}$ geochronology of weathering processes. Annu. Rev. Earth Planet. Sci. 27, 183-229.

Vasconcelos, P.M., Becker, T.A., Renne, P.R., Brimhall, G.H., 1992. Age and duration of weathering by ${ }^{40} \mathrm{~K}-{ }^{40} \mathrm{Ar}$ and ${ }^{40} \mathrm{Ar}-{ }^{39} \mathrm{Ar}$ analysis of supergene potassiummanganese oxides. Science 258, 451-455.

Vasconcelos, P.M., Conroy, M., 2003. Geochronology of weathering and landscape evolution, Dugald River valley, NW Queensland, Australia. Geochim. Cosmochim. Acta 67(16), 2913-2930. doi:10.1016/S0016-7037(02)01372-8

Vasconcelos, P.M., Heim, J.A., Farley, K.A., Monteiro, H., Waltenberg, K., 2013. ${ }^{40} \mathrm{Ar} /{ }^{39} \mathrm{Ar}$ and $(\mathrm{U}-\mathrm{Th}) / \mathrm{He}-{ }^{4} \mathrm{He} /{ }^{3} \mathrm{He}$ geochronology of landscape evolution and 
645 Vasconcelos, P.M., Renne, P.R., Becker, T.A., Wenck, H.R., 1995. Mechanisms and

646

647

648

649

650

651

652

653

654

655

656

657

658

659

660

661

662

663

664

665 kinetics of atmospheric, radiogenic, and nucleogenic argon release from cryptomelane during ${ }^{40} \mathrm{Ar} /{ }^{39} \mathrm{Ar}$ analysis. Geochim. Cosmochim. Acta 59, 20572070.

Vasconcelos, P.M., Renne, P.R., Brimhall, G.H., Becker, T.A., 1994a. Direct dating of weathering phenomena by ${ }^{40} \mathrm{Ar}^{39} \mathrm{Ar}$ and $\mathrm{K}$-Ar analysis of supergene K-Mn oxides. Geochim. Cosmochim. Acta 58, 1635-1665.

Vasconcelos, P.M., Wenck, H-R., Echer, C., 1994b. In situ study of the thermal behavior of cryptomelane by high-voltage and anlytical electron microscopy. Amer. Miner. 79(1-2), 80-90.

Widdowson, M., 1997. Tertiary paleosurfaces of the SW Deccan, Western India: implication for passive margin uplift, in: Widdowson, M. (Ed.), Palaeosurfaces: recognition, Reconstruction and Palaeoenvironmental Interpretation. Geological Society Special Publication, London, pp. 221-248.

Widdowson, M., Cox, 1996. Uplift and erosional history of the Deccan Traps, India: Evidence from laterites and drainage patterns of the Western Ghats and Konkan Coast. Earth Planet. Sci. Lett. 137, 57-69.

Widdowson, M., Gunnell, Y., 1999. Tertiary palaeosurfaces and lateritization of the coastal lowlands of western peninsula India, in: Thiry, M., Simon-Coinçon, R. (Eds.), Palaeoweathering, Palaeosurfaces and Related Continental Deposits. International Association of Sedimentologists, Special Publication, pp. 245-274. 


\section{Figures and table caption}

668 Figure 1. Simplified map of Peninsular India showing first-order geomorphic and 669 geological features (adapted from Radhakrishna, 1993). B= Bababudan; N= Nilghiris;

$670 \mathrm{~S}=$ Shevaroy.

671 Figure 2. Simplified geology of the Sandur Greenstone Belt adapted from Chadwick et

672 al. (1996). (b) Corresponding topography (ASTER GDEM30) and delineation of relicts 673 of paleosufaces S2 and S3. (c) Topographic cross-sections (lines of section are located 674 on Figure 2b).

675 Figure 3. North-looking Google Earth views of (a) Kappataswamy and (b) Channanghi 676 KMK-E pits showing the location of the cross-sections through the Mn ore bodies. (c)

677 Logs of sections 1 and 2. (d) Log of section 3. Black numbered samples are those 678 analysed and dated in the current study.

679 Figure 4. Characterisation of procedure used for separating cryptomelane grains in 680 samples. (a) Polished thin section observed by (b) reflected light microscopy and (c) X681 ray micro fluorescence, which yields a composite picture with $\mathrm{Mn}$ in blue, $\mathrm{K}$ in green 682 and Fe in red. (d) SEM image showing typical cryptomelane acicular crystals in a composite weathering matrix, which preserves altered quartz grains of the protore. $\mathrm{P}=$

684 pyrolusite; $\mathrm{C}=$ cryptomelane; $\mathrm{Pr}=$ protore; $\mathrm{Q}=$ quartz.

685 Figure 5. Reflected-light photomicrographs of mineral assemblages of dated samples 686 showing EPMA numbered targets. (a) Two generations of cryptomelane $(\mathrm{C} 1, \mathrm{C} 2)$ and 687 Pyrolusite (P) formed into the Mn protore (Pr). (b) Coexistence of two generations of 688 cryptomelane $(\mathrm{C} 1, \mathrm{C} 2)$ with pyrolusite $(\mathrm{P})$ and Fe-oxihydroxide $(\mathrm{Fe}) .(\mathrm{c})$ Crypomelane 
689 (C) and pyrolusite with some Fe-oxihydroxides (Fe). (d) Cavity filling by banded

690 overgrowth of a succession of cryptomelane (C) with pyrolusite (P) and a mixed

691 overgrowth on nsutite+ cryptomelane (NC). (e) Massive cryptomelane and pyrolusite

692 with some oxihydroxides (Fe). (f) Massive banded overgrowth of cryptomelane (C)

693 with pyrolusite (P), lithiophorite (L) and nsutite. Sample names are reported on each

694 photomicrograph.

695 Figure 6. X-ray diagrams of separated cryptomelane sub-samples. $\mathrm{C}=$ cryptomelane; $\mathrm{L}$

696 = lithiophorite; $\mathrm{n}=$ nsutite $\mathrm{Q}=$ quartz; $\mathrm{p}=$ pyrolusite $\mathrm{G}=$ goethite $\mathrm{h}=$ hematite

697 Figure $7 .{ }^{39} \mathrm{Ar}-{ }^{40} \mathrm{Ar}$ age spectra showing a well-defined plateau, with K/Ca (black) and 698 Ar* (grey) step curves (left), and inverse isochrone diagrams (right) of cryptomelane 699 separates from Kappataswamy open pit samples (a-c and e), and Channanghi KMK-E 700 open pit sample (d). MSWD = mean square weighted deviation.

701 Figure 8. Disturbed ${ }^{39} \mathrm{Ar}-{ }^{40} \mathrm{Ar}$ age spectra with K/Ca (black) and Ar* (grey) step curves 702 (left) and inverse isochrone diagrams (right) of cryptomelane separates from 703 Kappataswamy open pit samples. (a) Separated phase of KPA-2.5 (target 5 in Figure 704 5d). Samples KPA-2.5 and KPA-12a do not allow calculation of plateau age but only 705 maximum and minimum ages of the mixed youngest and oldest phases, respectively 706 (stippled line depicted from bold numbered steps in the spectra). MSWD = mean square 707 weighted deviation.

708

709 Table 1. Electron Probe Micro Analyses (EPMA) of targeted cryptomelane phases (in 710 bold) and other Mn oxides shown in the Figure 5. Each analyse is the average of three $7115 \mu \mathrm{m}$ micro spots in a $50 \mu \mathrm{m}$ sized micro domain. 


\section{Highlights}

* First radiochronological dating of lateritic weathering in southern India

* Late Palaeogene chemical weathering on the highest paleolandsurface preserved on the Mysore plateau and Deccan Traps

* Potential rejuvenation and acquisition of the current relief of southern India in the Neogene 


\section{igure.}

Click here to download Figure: Figure. 1(EPSL-D-13-00742).pdf

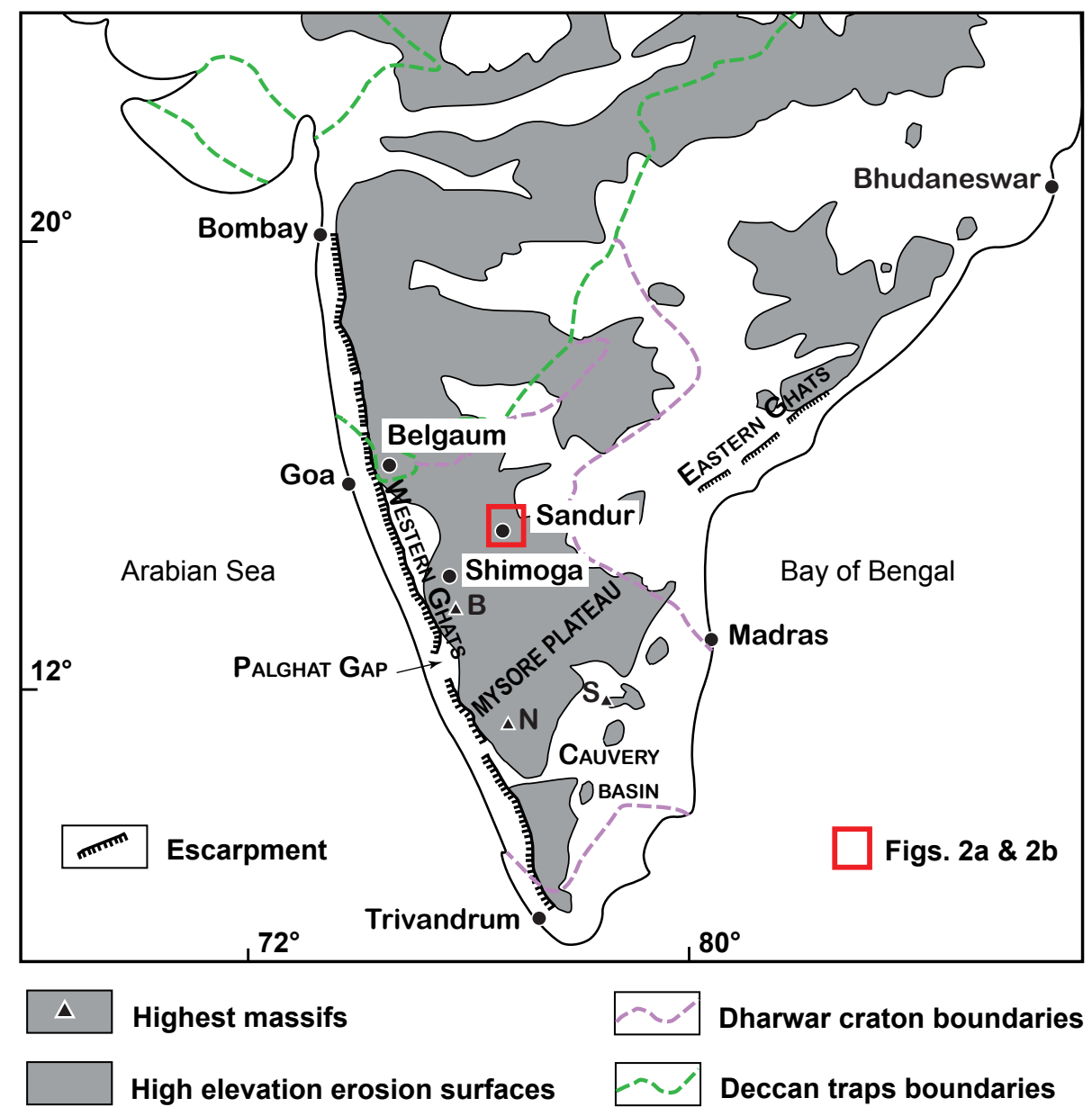

FIG. 1 


\section{Figure. 2}

Click here to download high resolution image
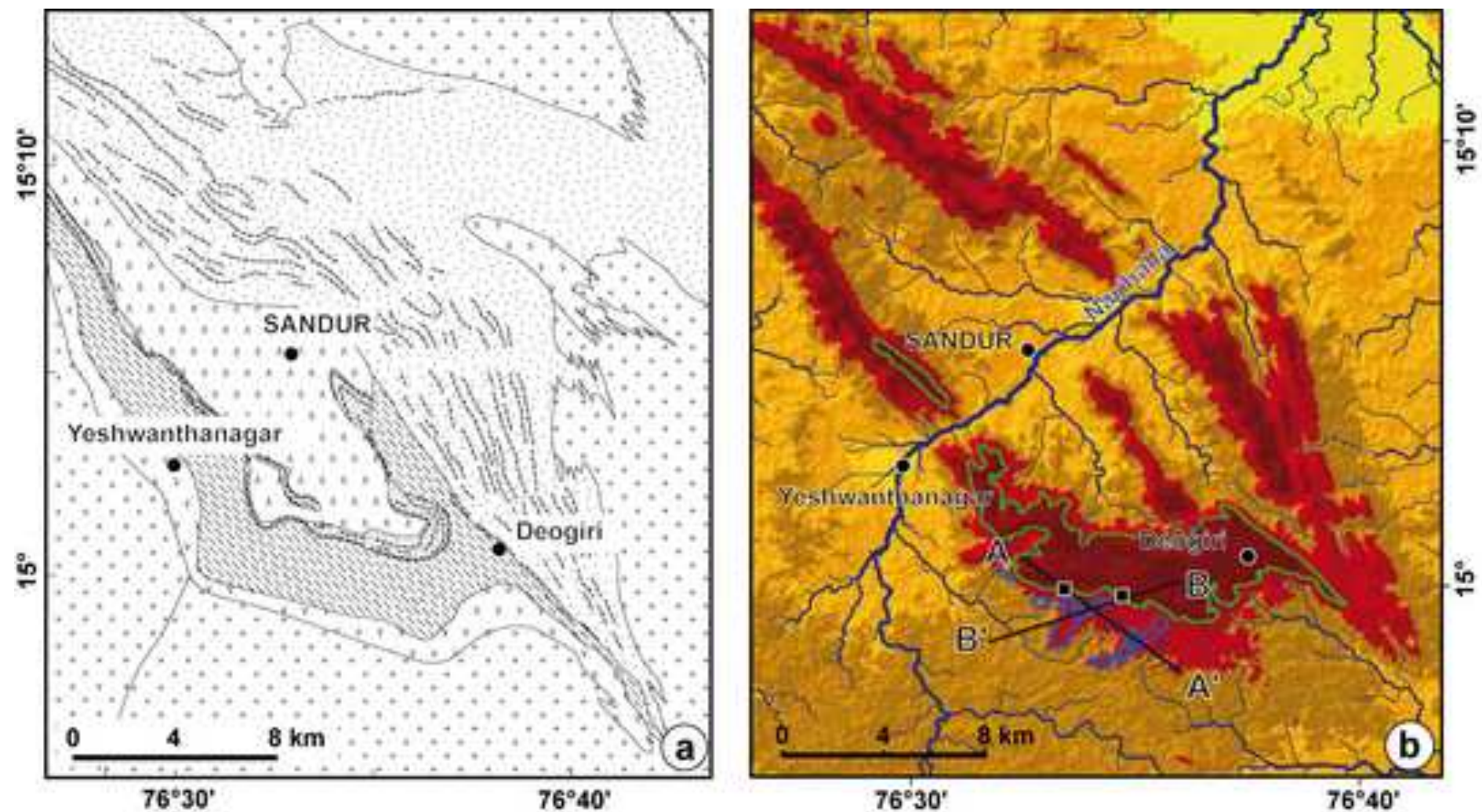

.. Closepet batholith

i... Mafic volcanics

$-7=$ BIF, felsic volcanics and terrigenous sediments

Fing Argillites, arenites, $\mathrm{Fe}-\mathrm{Mn}$ carbonates, phyllites

Yi. Basal mafic volcanics

Elevation ( $m$ )

G. Gneisses and migmatites

900-1114

$750-900$

$650-750$

$500-650$

$<500$
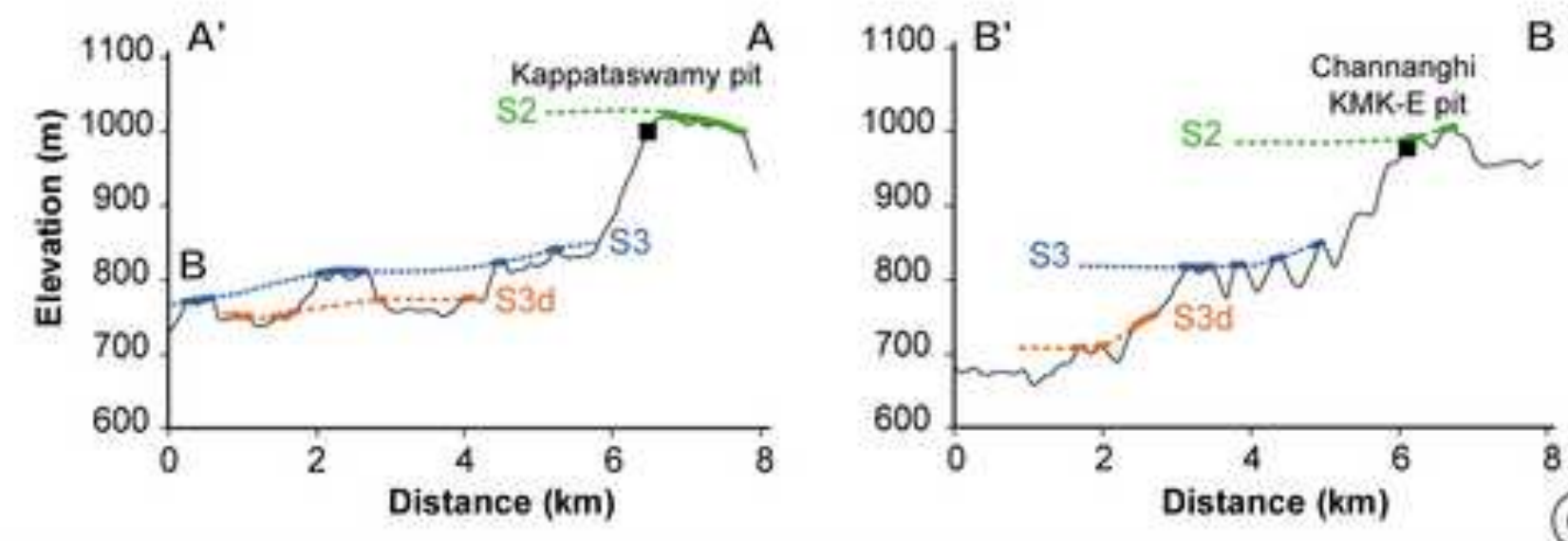
Figure. 3

Click here to download high resolution image

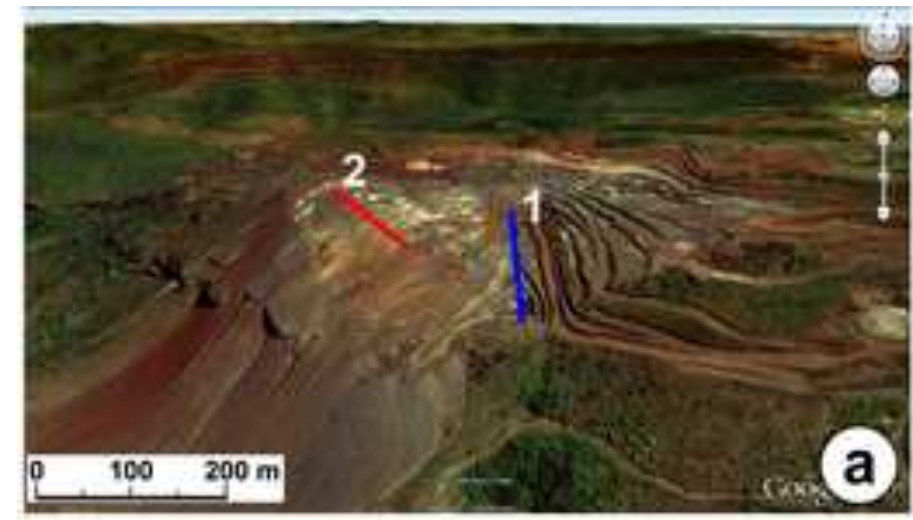

(b)

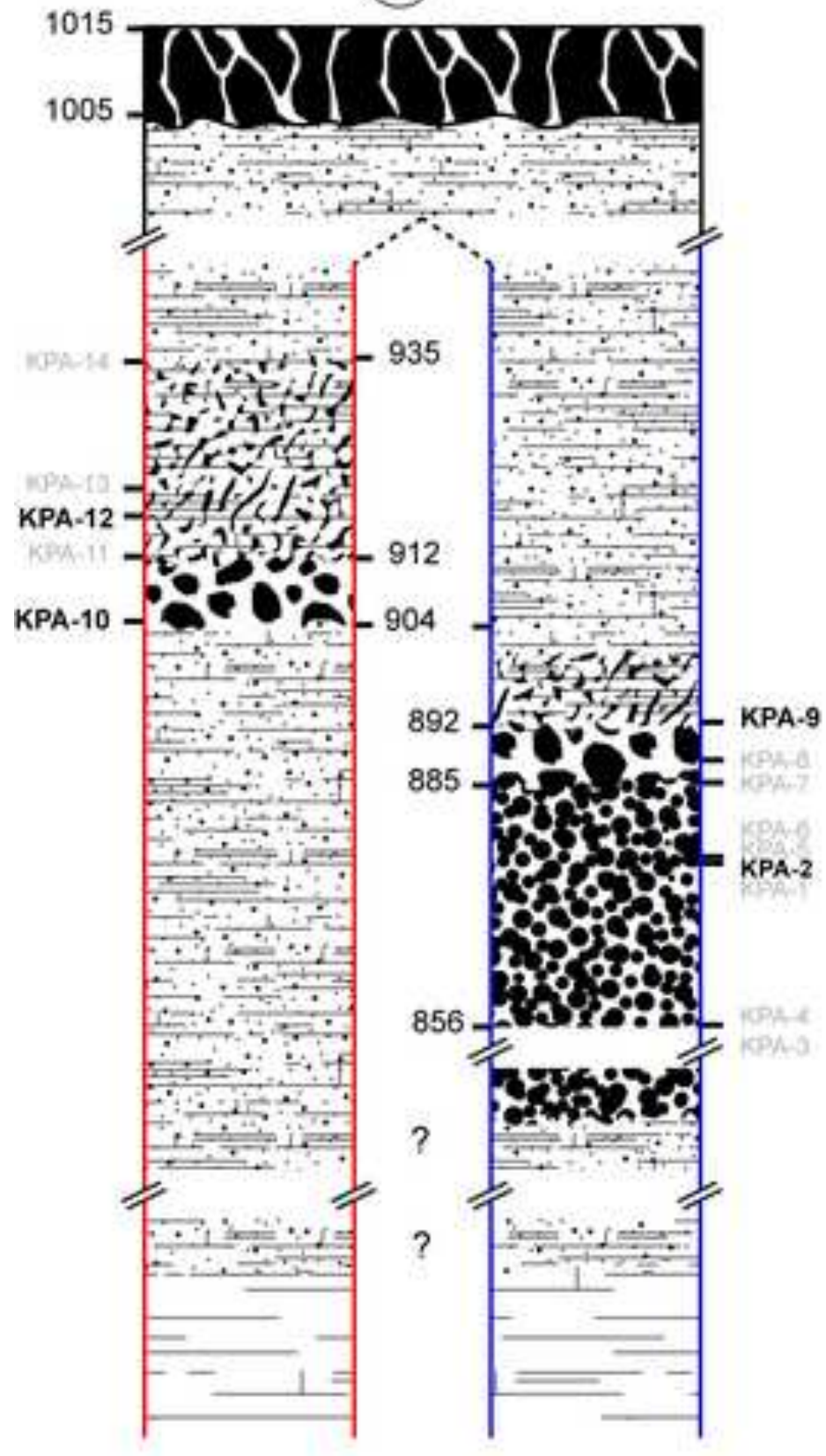

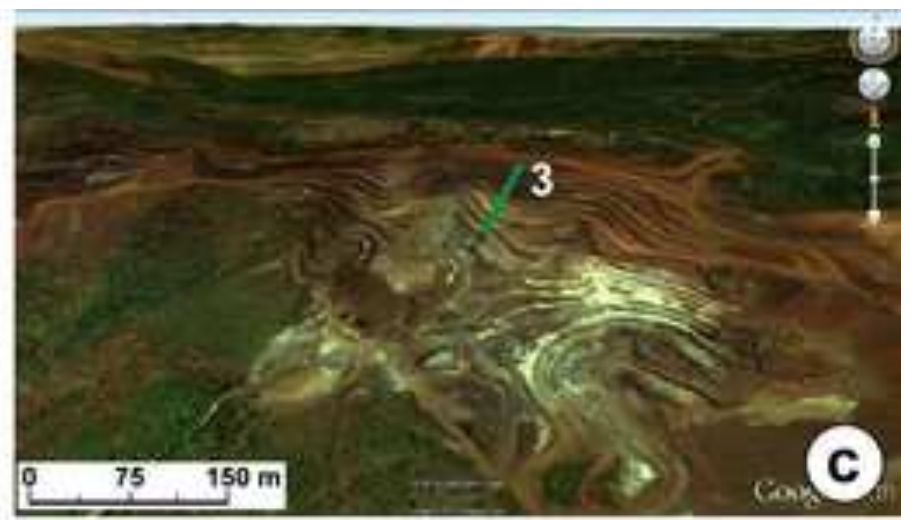

(d)

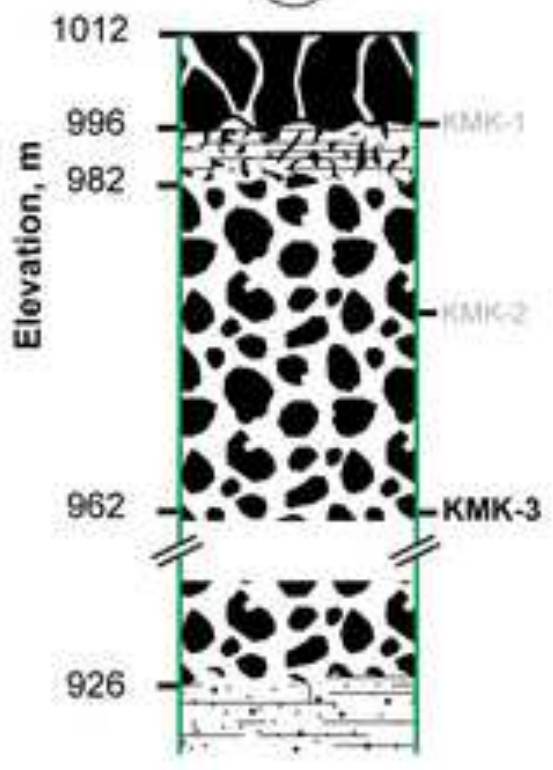

Lateritic Mn ore sequence

I. Fe-Mn massive duricrust

$2 / 21$ Platy Mn-ore with pods

T. Massive Mn-ore with cavities $>1 \mathrm{~cm}$

53 Massive Mn-ore with cavities $\leq 1 \mathrm{~cm}$

Float ore

Sedimentary protore (Mangan phyllites)

Section 1

Section 2

/ Section 3 
Click here to download high resolution image
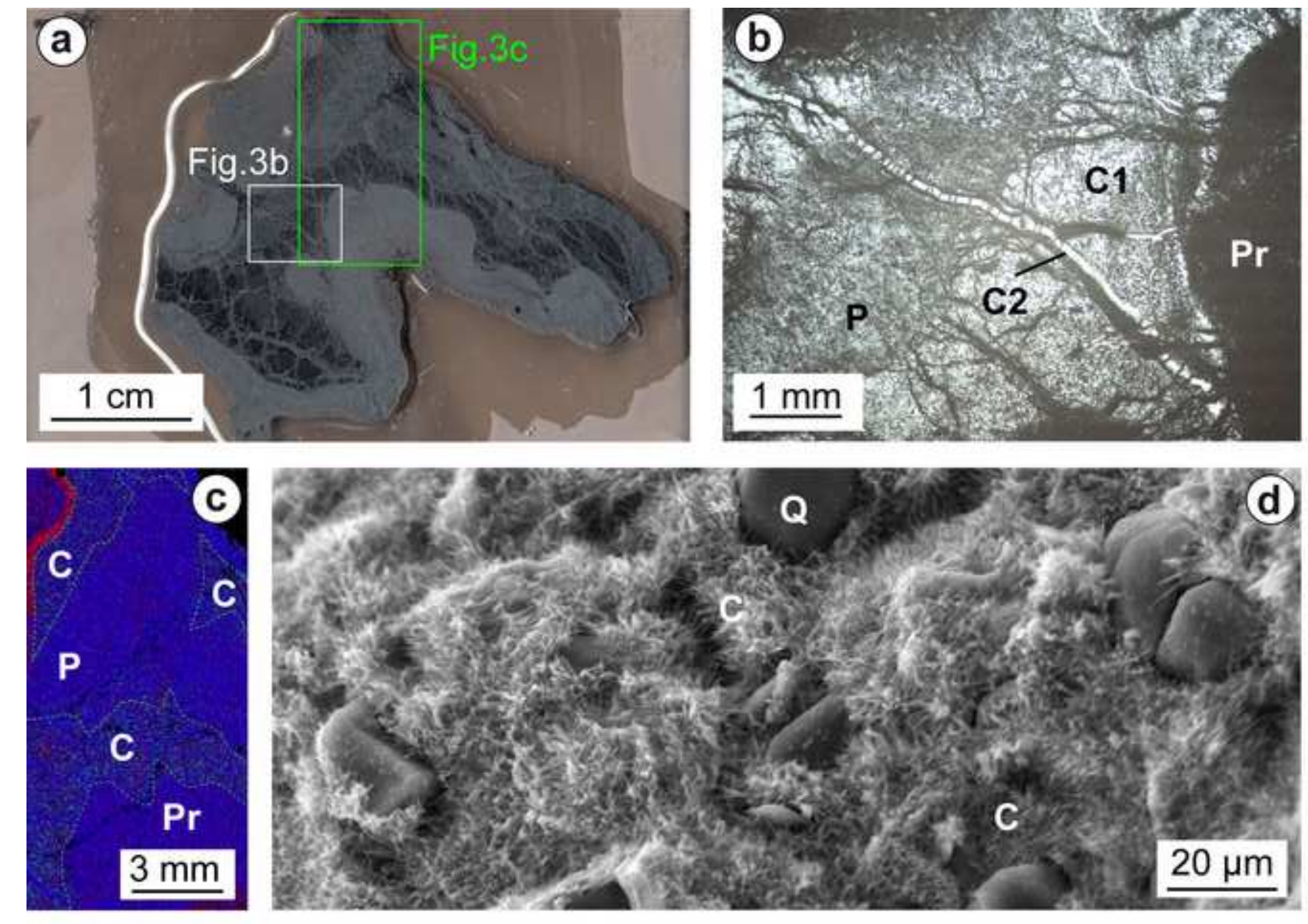

FIG. 4

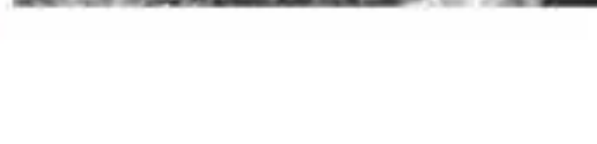




\section{Figure. 5}

Click here to download high resolution image
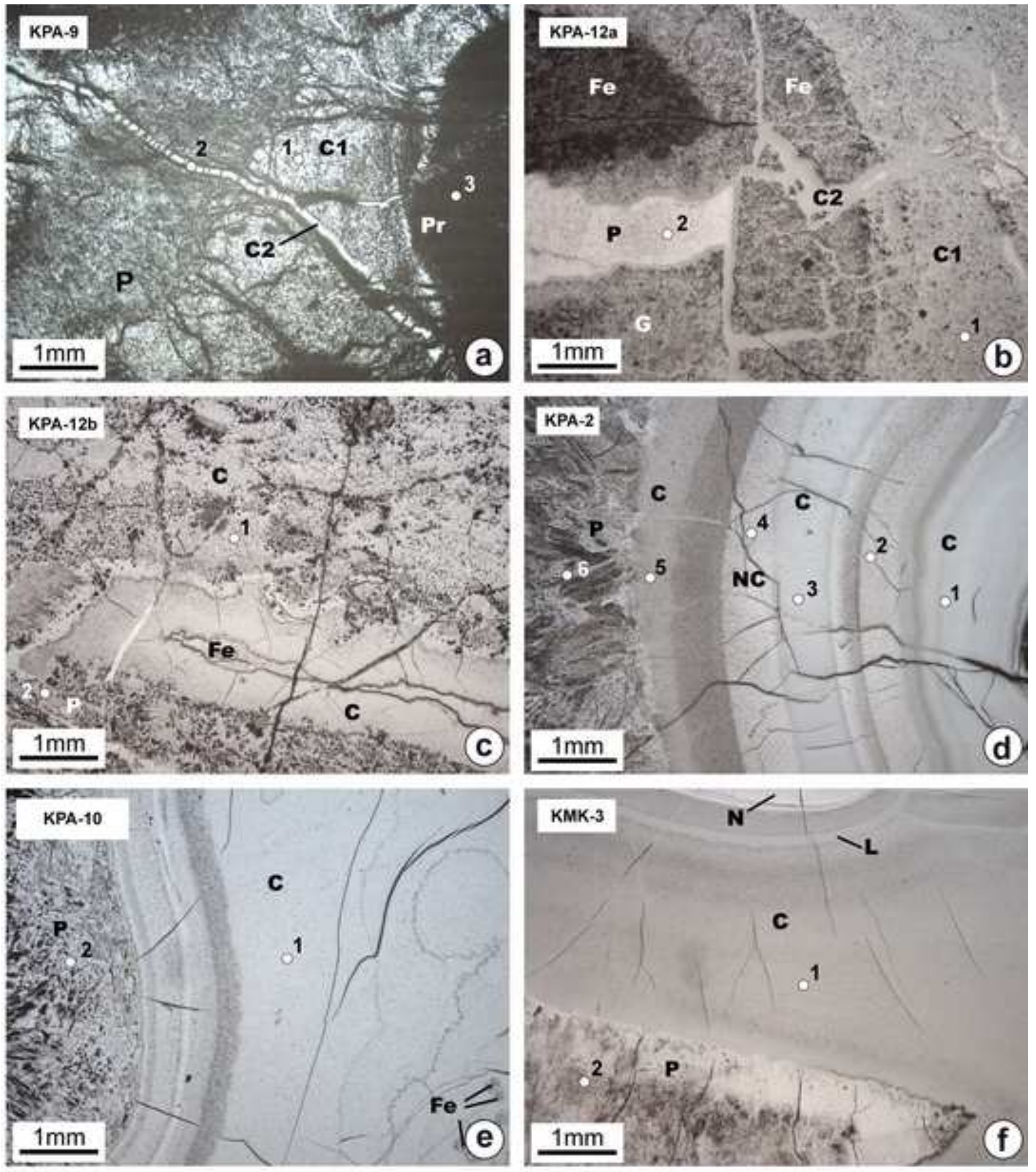

FIG. 5 
Figure. 6

Click here to download Figure: Flgure. 6(EPSL-D-13-00742).pdf

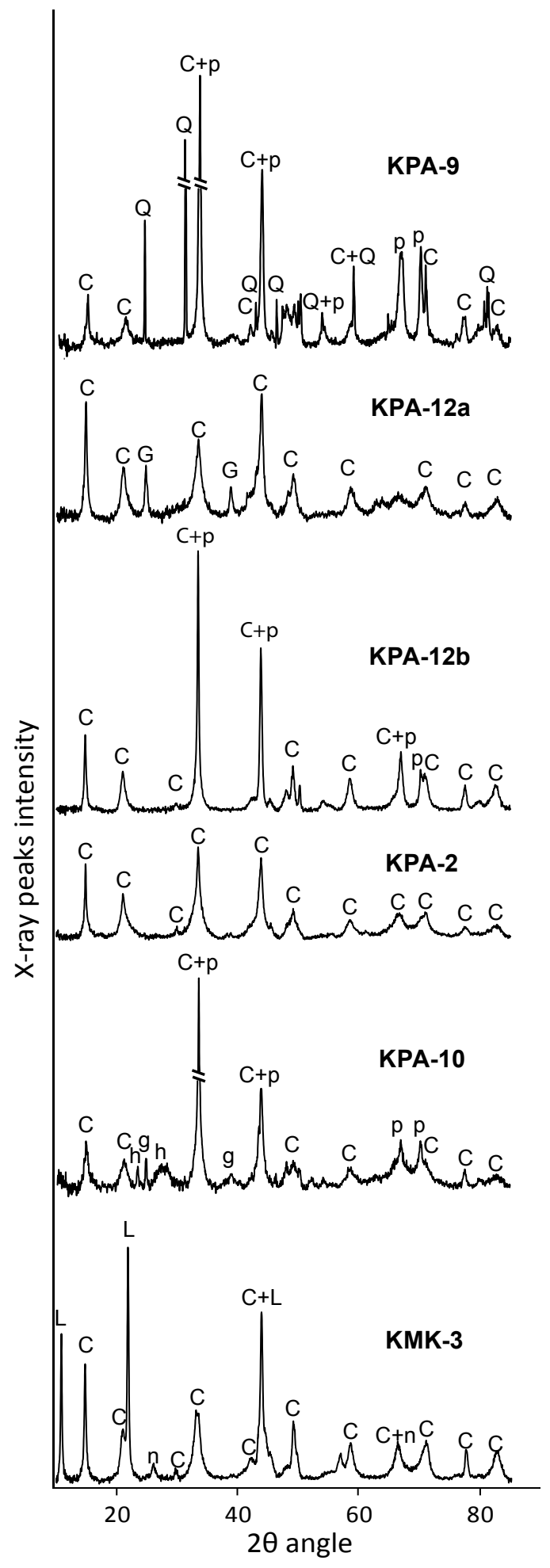

FIG. 6 


\section{gure. 7}

Click here to download Figure: Figure. 7(EPSL-D-13-00742).pdf
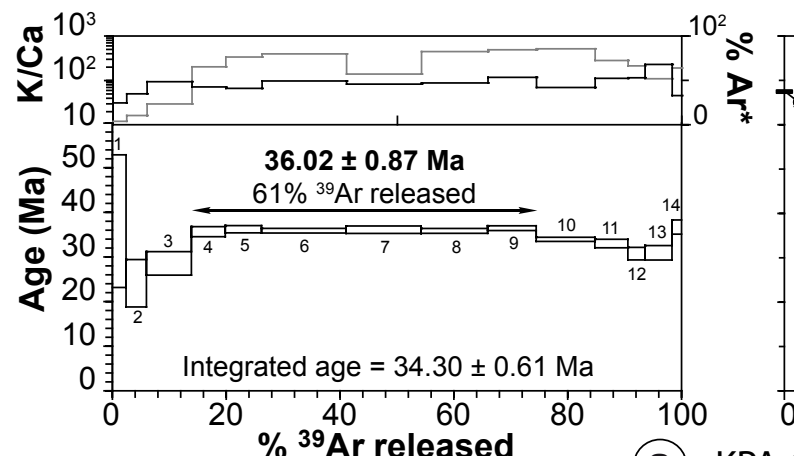

(a) $-\mathrm{KPA}-9$
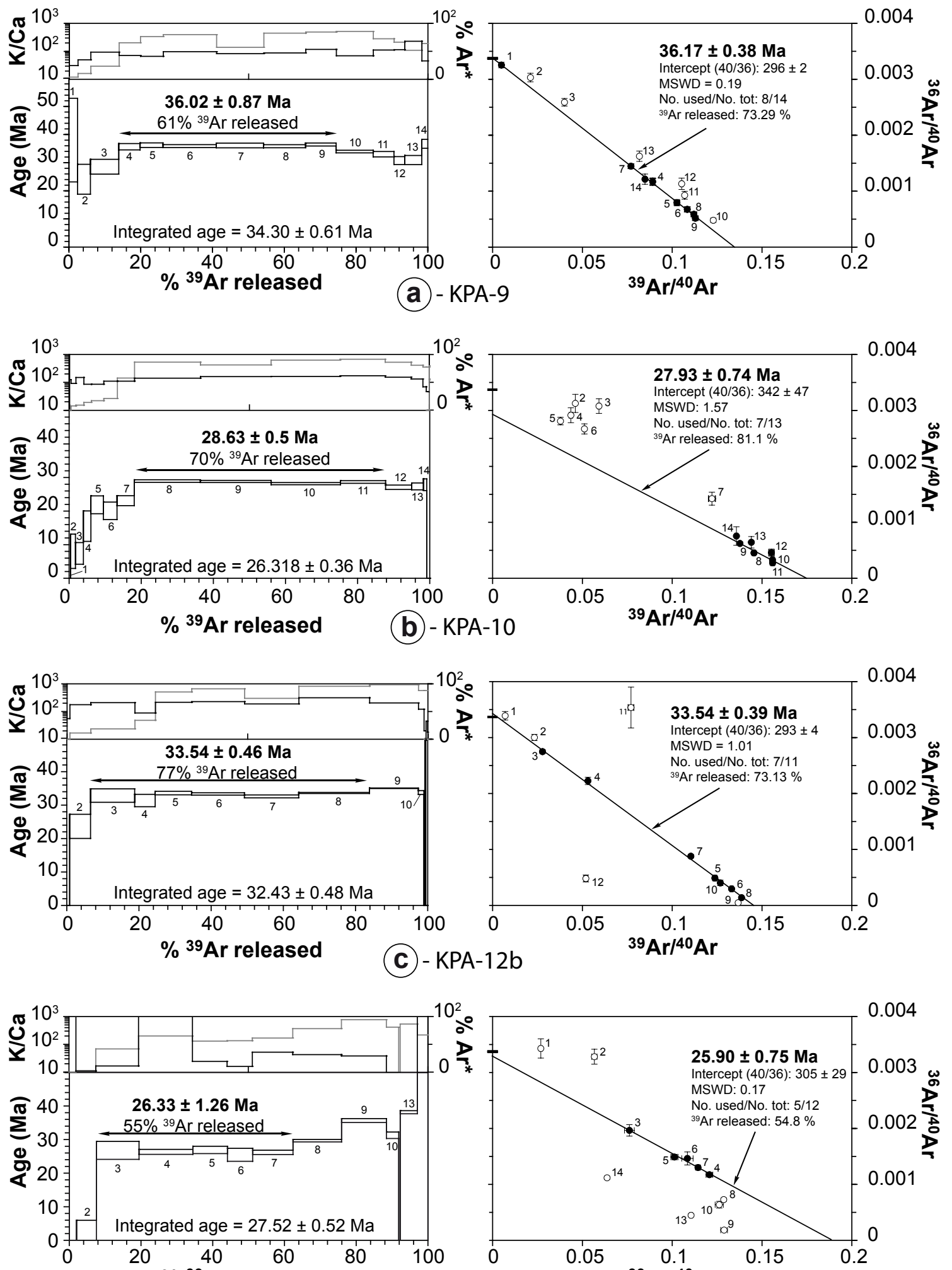

(d) $-\mathrm{KMK}-3$

.004

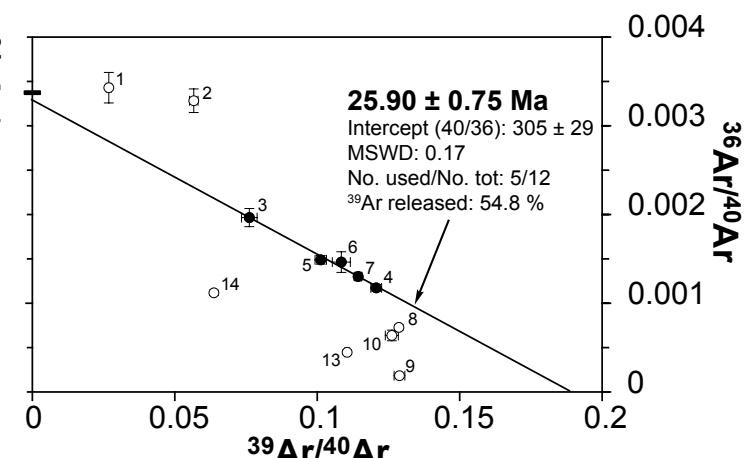

$10^{2}$
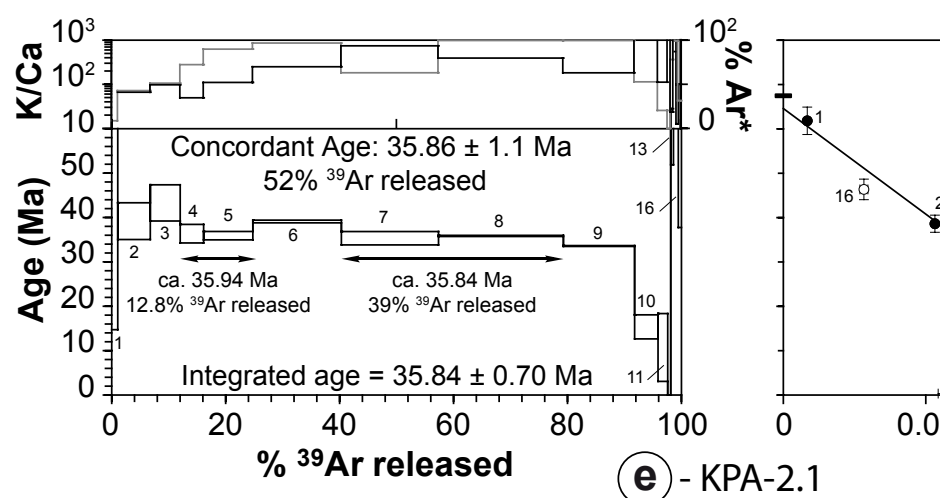

e) $-\mathrm{KPA}-2.1$

0.004

Intercept $(40 / 36)$ :

Intercept (40/36): $302 \pm$

11王 MSWD: 0.17

${ }^{39} \mathrm{Ar}$ released: $58.49 \%$

FIG. 7 
Figure. 8

Click here to download Figure: Figure. 8(EPSL-D-13-00742).pdf
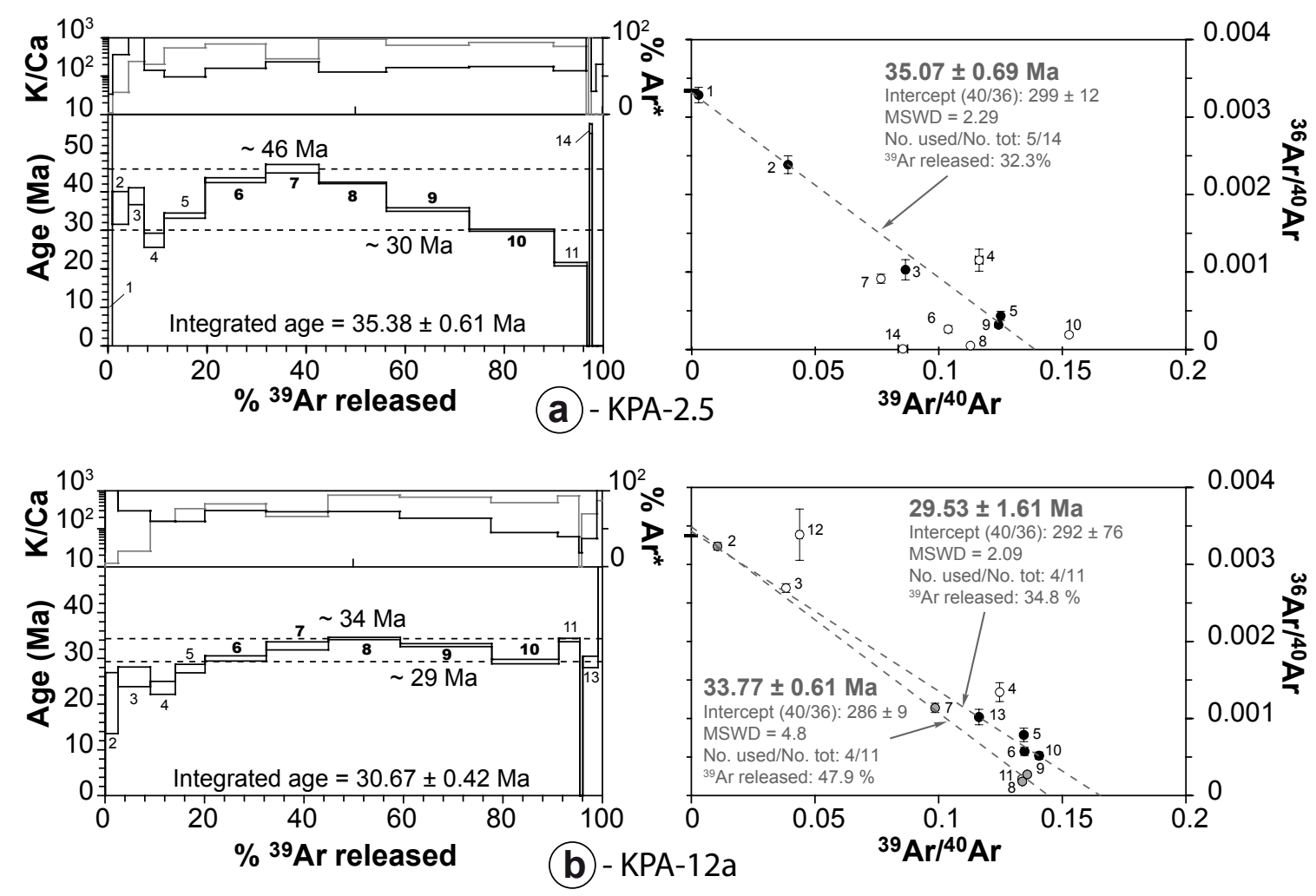

FIG. 8 


\begin{tabular}{|c|c|c|c|c|c|c|c|c|c|c|c|c|c|c|c|c|c|}
\hline \multirow[t]{3}{*}{\begin{tabular}{|c} 
Sample \\
ID
\end{tabular}} & \multicolumn{2}{|c|}{ KMK-3 } & \multicolumn{6}{|c|}{ KPA-2 } & \multicolumn{3}{|c|}{ KPA-9 } & \multicolumn{2}{|c|}{ KPA-10 } & \multicolumn{2}{|c|}{ KPA-12a } & \multicolumn{2}{|c|}{$\mathrm{KPA}-12 \mathrm{~b}$} \\
\hline & 1 & 2 & 1 & 2 & 3 & 4 & 5 & 6 & 1 & 2 & 3 & 1 & 2 & 1 & 2 & & 2 \\
\hline & $\mathrm{C}$ & $\mathrm{P}$ & $\mathrm{C}$ & $\mathrm{C}$ & $\mathrm{C}$ & $\mathrm{C}$ & $\mathbf{C}$ & $\mathrm{P}$ & $\mathrm{C}$ & $\mathrm{C}$ & $\operatorname{Pr}$ & $\mathbf{C}$ & $\mathrm{P}$ & $\mathrm{C}$ & $\mathrm{P}$ & $\mathrm{C}$ & $\mathrm{P}$ \\
\hline wt. \% & 6015 & 6097 & 5972 & 6001 & 5938 & 6107 & 5913 & 6295 & 56.62 & 57.52 & 1238 & 5911 & 6067 & 5910 & 6186 & 5982 & 6037 \\
\hline $\mathrm{Al}$ & $\begin{array}{l}0.10 \\
0.15\end{array}$ & 0.30 & 0.12 & 0.30 & 0.22 & 0.33 & 0.20 & 0.00 & 1.41 & 1.24 & 0.37 & 0.20 & 0.29 & 0.45 & 0.11 & 0.18 & 0.37 \\
\hline $\mathrm{Fe}$ & 0.13 & 0.13 & 0.12 & 0.13 & 0.13 & 0.13 & 0.13 & 0.14 & 0.58 & 0.51 & 0.17 & 0.05 & 0.13 & 0.81 & 0.14 & 0.17 & 0.85 \\
\hline K & 1.41 & 0.06 & 2.49 & 2.26 & 2.44 & 0.94 & 3.03 & - & 2.13 & 2.19 & 0.50 & 2.65 & 0.87 & 2.19 & 0.19 & 3.29 & 0.29 \\
\hline $\mathrm{Na}$ & 0.03 & 0.01 & 0.09 & 0.14 & 0.11 & 0.03 & 0.08 & - & 0.06 & 0.08 & 0.01 & 0.10 & 0.13 & 0.08 & 0.02 & 0.07 & 0.01 \\
\hline $\mathrm{Zn}$ & - & - & 0.01 & 0.02 & 0.02 & 0.01 & 0.02 & - & 0.01 & 0.02 & 0.01 & 0.01 & 0.01 & 0.01 & 0.01 & 0.01 & 0.01 \\
\hline Co & - & - & - & - & - & 0.01 & - & - & 0.01 & 0.01 & 0.01 & - & 0.01 & 0.01 & - & 0.01 & 0.01 \\
\hline $\mathrm{Ba}$ & 0.07 & 0.02 & 0.01 & - & - & 0.01 & 0.01 & 0.01 & 0.01 & 0.01 & - & 0.01 & - & - & 0.01 & 0.01 & 0.02 \\
\hline $\mathrm{Ni}$ & - & - & - & - & - & - & - & - & - & - & - & - & - & - & - & - & - \\
\hline $\mathrm{Ti}$ & - & - & - & - & - & - & - & - & 0.01 & 0.01 & - & - & - & - & - & - & - \\
\hline $\mathrm{Mg}$ & - & 0.00 & 0.01 & 0.01 & 0.01 & 0.01 & $\mathbf{0 . 0 0}$ & - & 0.01 & 0.01 & - & 0.02 & 0.01 & 0.01 & - & 0.00 & 0.02 \\
\hline $\mathrm{Si}$ & 0.06 & 0.33 & 0.07 & 0.08 & 0.06 & 0.09 & 0.07 & 0.08 & $\mathbf{0 . 3 8}$ & 0.20 & 37.58 & 0.06 & 0.10 & 0.08 & 0.17 & 0.07 & 0.12 \\
\hline $\mathrm{Ca}$ & 0.02 & 0.04 & 0.12 & 0.10 & 0.11 & 0.06 & 0.11 & 0.00 & 0.11 & 0.12 & 0.02 & 0.18 & 0.10 & 0.11 & 0.04 & 0.13 & 0.15 \\
\hline $\mathrm{O}$ & 35.59 & 36.23 & 35.60 & 35.92 & 35.49 & 36.24 & 35.44 & 36.80 & 35.35 & 35.52 & 50.53 & 35.36 & 36.02 & 35.68 & 36.44 & 35.89 & 36.02 \\
\hline Total & 97.62 & 98.11 & 98.36 & 98.98 & 97.99 & 98.92 & 98.24 & 99.99 & 96.68 & 97.41 & 101.6 & $\mathbf{9 7 . 7 5}$ & 98.35 & 98.53 & 98.99 & 99.64 & 98.24 \\
\hline \multicolumn{18}{|c|}{ Stoichiometric composition of cryptomelane based on 16 oxygens } \\
\hline $\mathrm{K}$ & 0.4 & & 0.45 & 0.41 & 0.45 & 0.17 & 0.57 & & 0.42 & 0.4 & & 0.5 & & 0.4 & & 0.61 & \\
\hline $\mathrm{Mn}^{\mathrm{IV}}$ & 7.6 & & 7.55 & 7.59 & 7.55 & 7.83 & 7.43 & & 7.58 & 7.6 & & 7.5 & & 7.6 & & 7.39 & \\
\hline $\mathrm{Mn}^{\mathrm{III}}$ & 0.4 & & 0.45 & 0.41 & 0.45 & 0.17 & 0.57 & & 0.42 & 0.4 & & 0.5 & & 0.4 & & 0.61 & \\
\hline
\end{tabular}

$-:$ not detected $; \mathrm{C}=$ Cryptomelane $; \mathrm{P}=$ Pyrolusite $; \mathrm{Pr}=\mathrm{Si}-\mathrm{Mn}$ protore

Table. 1 
Data repositories Tables
Click here to download S

Click here to download Supplementary material for on-line publication only: DataRepositoryTables(EPSL-D-13-00742).pdf 
Data repositories Main text

Click here to download Supplementary material for on-line publication only: Data repositories(EPSL-D-13-00742)-Main text.doc 